\title{
O atual sistema de solução de controvérsias do Mercosul: rumo à consolidação de um tribunal regional*
}

\section{The current dispute settlement system of Mercosur: towards the consolidation of a regional court}

\section{Resumo}

O presente artigo tem por objeto a análise do atual Sistema de Solução de Controvérsias do Mercosul. E esta análise comporta três âmbitos. Em primeiro lugar, pretende-se dar uma visão panorâmica da organização dentro da qual o Sistema de Solução de Controvérsias se insere; em segundo lugar, o Sistema será analisado sob o ponto de vista evolutivo da normativa que o norteia; por último, o mecanismo será apreciado do ponto de vista laboral, sob a observância de sua atuação prática. A proposta deste artigo é apresentar a atualidade do Sistema sem, entretanto, esbarrar em uma exposição teórica prostrada nas normas mercosulinas. Nosso centro de análise é a evolução normativa aplicada ao comportamento dos Tribunais frente às controvérsias que se apresentam. Este artigo, portanto, comporta 3 (três) marcos simbólicos. O primeiro é introduzir o processo de integração no qual se insere o Mercosul; o segundo é conhecer o Sistema de Solução de Controvérsias e sua normativa evolutiva, destacando especialmente que a vinda de um órgão jurisdicional multifuncional no Mercosul favoreceu o alargamento de suas competências e instâncias. Além disso, sua chegada veio afastar uma parcela da importância conferida aos Tribunais ad hoc e possibilitar a consolidação futura de um Tribunal regional. E o terceiro é adentrar a prática laboral do Sistema de Solução de Controvérsias sob o Protocolo de Olivos e conhecer a única atuação prática desse amplo Tribunal, observando que seu funcionamento é de vital importância para perceber a evolução do Sistema e suas aspirações.

Palavras-chave: Sistema de Solução de Controvérsias. Mercosul. Direito da integração. Protocolo de Olivos. Órgão judicial permanente.

\footnotetext{
* Artigo recebido em 28/09/2011 Aprovado em 28/10/2011

1 Mestre em Direito, na área de Ciências Jurídico-Internacionais pela Faculdade de Direito da Universidade de Lisboa (FDUL), Especialista em Direito Internacional pela mesma instituição. Foi Vice-Presidente do Núcleo de Estudantes Luso-brasileiros (NELB) na FDUL e Colaboradora do Gabinete de saídas profissionais da mesma instituição.
} 
Mercosur standards. Our analysis center is the evolution rules applied to the behavior of the courts in the face of controversies that arise. This article, therefore, contains three symbolic landmarks. The first is to introduce the integration process in which you insert the Mercosur and the second is knowing the dispute settlement system and its regulatory evolution, especially highlighting that the coming of a multifunctional court in Mercosur favored the extension of its powers and authorities. Moreover, his arrival came away a portion of the importance given to ad hoc tribunals and enable the future consolidation of a Regional Court, the third is to enter the labor practice under the Protocol of Olivos and the only known practical application of this broad Court, noting that its operation is of vital importance to understand the evolution of the system and their aspirations.

Keywords: Dispute settlement system. Mercosul. Integration Law. Olivos Protocol. Permanent judicial body.

\section{Mercosul}

Um processo de integração pode ser constituído de diversas formas. Deve-se, entretanto, ter como pressuposto geral a vontade dos estados em querer conformá-lo, seja para que fim for. ${ }^{2}$

No caso específico do Mercosul, houve a necessidade de conformação de um bloco econômico diante da realidade mundial presenciada. Os processos integracionistas que se insurgiram anteriores à conformação desse bloco motivaram os quatro países a conformarem um mercado comum sob a premissa de maior desenvolvi-

\footnotetext{
2 Os processos integracionistas poderão ser criados para diversos fins. Manuel Diez de, VELLASCO, Manuel Diez de. Las organizaciones internacionales. Madrid: Tecnos, 1999. p. 45-46. Segundo o autor, existem organizações que perseguem fins gerais, estas, em menor número, e outras que são criadas atendendo fins específicos, as quais correspondem à maior parte delas. Como fins específicos enquadram-se as organizações criadas para fins de cooperação militar ou de segurança (ex.: OTAN), organizações de cooperação preferentemente econômica (Ex: Mercosul, OMC), organizações de cooperação social, cultural e humanitária (Ex: UNESCO) e as organizações de cooperação para fins técnicos e científicos. Ver também: GRECO, Leonardo. Solução de controvérsias e protocolos do Mercosul. Revista brasileira de direito comparado, Rio de Janeiro, n. 16, p. 111, Abr 1999. O autor posiciona-se sobre a existência de 5 (cinco) requisitos para que a integração regional seja alcançada.
}

mento das relações econômicas recíprocas e da livre circulação de bens. ${ }^{3}$

Constituído por meio do Tratado de Assunção, em 26 de março de 1991, o Mercosul ou Mercado Comum do Sul veio no momento de um imperativo no que toca às relações econômicas vivenciadas entre seus Estados-Membros: Argentina, Brasil, Paraguai e Uruguai. ${ }^{4}$

Seu propósito inicial era precipuamente a conquista de um mercado comum, ${ }^{5}$ uma união aduaneira sem fronteiras alfandegárias, ${ }^{6}$ de modo que bens, serviços e fatores produtivos circulariam sem quaisquer restrições protecionistas. A condição era que o bloco econômico devesse conformar-se no prazo médio de três anos, no emplacar de tarefas que trouxessem a evolução rumo à construção de uma zona de livre comércio.

3 No âmbito americano, processos integracionistas como a Comunidade Andina (CAN) criada por meio do Acordo de Cartagena, em 1969, sob a designação de Pacto Andino; e em âmbito europeu a União Europeia instituída primeiramente como Comunidade Europeia do Carvão e do Aço pelo Tratado de Paris, em 1951.

4 EKMEKDJIAN, Miguel Angel. Introducción al derecho comunitario latinoamericano: con especial referencia al Mercosur. Buenos Aires: Depalma, 1996. p. 147 e ss. O autor vem trilhar a evolução dos acordos entre Argentina e Brasil que contribuíram especialmente para a conformação do Mercosul. Relembra de forma cronológica que as relações para conformação de uma integração sul-americana começaram com o Acordo do Rio da Prata entre Argentina, Brasil, Bolívia, Paraguai e Uruguai, acordo este de natureza econômico-hidrográfica que permitia a navegação e trocas comerciais por uma extensão aproximada de $5.000 \mathrm{~km}$; No tocante às relações bilaterais Brasil-Argentina, as animosidades que existiam deram lugar ao Acordo Tripartido Argentina-Brasil- Paraguai; a Cooperação na área nuclear entre os dois países; a Declaração de Foz de Iguaçu, em 1985 e, um ano mais tarde, a Ata para Integração Argentino-brasileira na qual foi estabelecido um programa de integração e cooperação econômica entre os dois países; A Ata de Buenos Aires foi o marco para a conformação de um mercado comum, o qual, fundamentalmente, gerou o Tratado Constitutivo do Mercosul.

5 O Laudo Arbitral do Mercosul de 28 de abril de 1999 em Fundamentos Jurídicos, considerando 16, vem trazer o conceito de Mercado Comum, lembrando que "o Tratado de Assunção expressa que o mercado comum implica, entre outras coisas, eliminar os direitos aduaneiros e as restrições não tarifárias e qualquer outra medida equivalente."

6 MARQUES, Claudia Lima. O "Direito do Mercosul": direito oriundo do Mercosul, entre Direito Internacional clássico e novos caminhos de integração. Revista da Universidade Federal do Paraná, Curitiba, v. 35, n. 1, p. 74, Jan 2001. Nesse sentido, a autora expressa que o Tratado de Assunção criou o Mercosul com o principal propósito de remover as barreiras tarifárias entre os países-membros. 
O bloco, no entanto, veio experimentar caminhos em direção ao que se acredita, encontra-se fora de seu campo estratégico. E apesar do desafio de construção do Mercado Comum ainda permanecer ativo, outras áreas como, meio ambiente, educação e redução de assimetrias entraram na pauta de assuntos que o bloco passou a tratar.

Acordos importantes de caráter econômico foram selados, além de outros que vêm demonstrar a incidência dinâmica do bloco sobre questões não estritamente econômicas. ${ }^{7}$ Além disso, outras questões comportam-se igualmente como objetos de solidez, tais como: (i) a incorporação de sua normativa e o fortalecimento institucional; (ii) as questões de acesso ao mercado e agilidade dos trâmites em fronteira; (iii) incentivos aos investimentos, à produção e à exportação, incluindo as zonas francas; (iv) a admissão temporária e outros regimes especiais; (v) tarifa externa comum; e (vi) defesa comercial e defesa da concorrência, além do amadurecimento de suas relações externas.

O Mercosul mostra-se mutável a adaptável a um processo evolutivo cujos patamares vêm sendo erguidos de acordo com as necessidades que emanam do bloco, e daquelas que estejam de acordo com seus objetivos de desenvolvimento. Assumida sua natureza transitória nos próprios instrumentos em seu seio criados, o Mercosul evoluiu rumo à criação de um Sistema de Solução de Controvérsias e, na atualidade, visa aprofundá-lo.

Criado por meio do Protocolo de Olivos, esse Sistema atualmente trilha um caminho rumo à consolidação de um tribunal regional. Como poderemos analisar no presente artigo, o Tribunal Permanente de Revisão (TPR) ocupa-se hoje de um papel importantíssimo, especialmente no que toca à sua capacidade de impugnar as decisões emanadas dos Tribunais ad hoc, que, até a introdução do PO em vigor desde 2004, eram os responsáveis

\footnotetext{
7 Dentre os acordos que visam ao desenvolvimento econômico, enquadram-se o celebrado entre Mercosul e Paquistão sob a Dec. n. 07/06 sobre liberalização do comércio e, igualmente, o recente acordo envolvendo Mercosul e Israel para estreitamento das trocas comerciais bilaterais. Há medidas, entretanto, que buscam desenvolver outras questões, como o Plano Estratégico de Ação social do Mercosul, firmado em 15 de dezembro de 2008, com o objetivo de reduzir o déficit social, promover o desenvolvimento humano integral e a integração produtiva; Aprovação do Plano Marco de Ciência, Tecnologia e Inovação do Mercosul sob a Dec. CMC n. 03/08 que vigorará no período de 2008 a 2012.
}

pela proferição de decisões inapeláveis e por vezes pouco comprometidas com a realidade do Mercosul.

\section{0 sistema de solução de controvérsias}

O Sistema de Solução de Controvérsias do Mer$\operatorname{cosul}^{8}$ nasceu da necessidade de se criar uma estrutura capaz de atender às questões de dissenso e de conflitos que surgissem das relações entre os Estados e, mais do que isso, de alcançar os objetivos predispostos no Tratado de Assunção. Além disso, era necessária a conformação de um sistema como arena para solução de litígios que viesse a conferir maior segurança jurídica aos Estados-Membros do Mercosul.

Inspirado no modelo de Haia, adaptado aos sistemas de cooperação econômica e na experiência do GATT, o Sistema de Solução de Controvérsias do Mercosul é iniciado pela adoção da jurisdição facultativa expressada por meio dos Tribunais ad hoc e também pela fase de negociações diretas, preliminar à fase litigiosa ou judicial. ${ }^{9}$

\subsection{A evolução da normativa do sistema}

O Tratado de Assunção, firmado em 26 de março de 1991, estabeleceu em primeiro lugar as normas referentes às controvérsias que surgissem no processo de transição do tão almejado mecanismo que nasceria no âmbito do Mercosul. Em seu Anexo III, foram estabelecidas as fases concernentes à controvérsia, na qual o documento limitou-se a assegurar a solução de litígios às instâncias cabíveis. Além disso, dispôs que o almejado Sistema Permanente de Solução de Controvérsias possuía data limite para ser implementado, já que até 31 de

\footnotetext{
8 O Sistema de Solução de Controvérsias do Mercosul poderá ser mencionado sob a sigla SSCM.

9 BAPTISTA, Luis Olavo. Solução de divergências no Mercosul. In: _. Mercosul: seus efeitos jurídicos, econômicos e políticos nos Estados-Membros. Porto Alegre: Apiliada, 1997.p. 164, considera que o GATT é o "primeiro esforço" de adaptação dos sistemas de cooperação econômica aos mecanismos de consulta dos painéis técnicos e recomendações às partes contratantes.
} 
dezembro de 1994 deveria estar em funcionamento. ${ }^{10}$ No entanto, os Estados-Membros resolveram pela adoção de um Protocolo anexo ao Tratado de Assunção elaborado em Brasília que veio dispor de um sistema suscetível à reforma e às alterações sensíveis até que fosse verdadeiramente conformado, como veremos no ponto seguinte.

O crescimento do Sistema de Solução de Controvérsias foi formalizado mediante a elaboração de seus Protocolos e tendo como paradigma as normas estabelecidas no Direito Originário do Mercosul. A partir desse referencial, a necessidade de evolução justificada precipuamente pelas demandas surgidas entre os Estados-Membros e, de forma subsidiária entre esses Estados e pessoas físicas ou jurídicas, tornou imperiosa a introdução de uma normativa mais completa, que conferisse maior segurança jurídica aos contratantes e gradativamente preenchesse as lacunas vigentes na normativa mercosulina para solução de litígios.

\subsubsection{Protocolo de Brasília ${ }^{11}$}

O Protocolo de Brasília assinado em 17 de dezembro de 1991 foi instituído pela importância de se dispor de um instrumento eficaz de garantia ao cumprimento do Tratado de Assunção para a adoção de um sistema vigorante durante o período de transição.

Na verdade, o Protocolo de Brasília nasceu da exigência de se conformar o escopo normativo do Sistema de forma ágil. Logo, primeiramente, o documento determina a ratione materiae do SSCM, que versará:

[...] sobre a interpretação, a aplicação ou o não cumprimento das disposições contidas no Tratado de Assunção, dos acordos celebrados no âmbito do mesmo, bem como das decisões do Conselho do Mercado Comum e das resoluções do Grupo Mercado Comum [...]. ${ }^{12}$

O Sistema de Solução de Controvérsias adotado nessa fase do Mercosul comporta três fases, determinadas como as três etapas máximas cabíveis para por termo

${ }^{10} \mathrm{O}$ Anexo III do Tratado de Assunção estabelece que a solução de controvérsias deve ser buscada, em princípio, pelas negociações diretas, em caso de não resolução seriam levadas à consideração do Grupo Mercado Comum (GMC) que após avaliar a controvérsia formulava recomendações pertinentes as partes. Sendo cabível o estabelecimento ou convocação de painéis de especialistas.

${ }^{11}$ O Protocolo de Brasília poderá ser mencionado sob a sigla $\mathrm{PB}$.

${ }^{12}$ Artigo $1^{\circ}$ do PB. à questão litigiosa. São elas: (i) a negociação direta; (ii) a conciliação; e (iii)

a etapa arbitral. A primeira fase, também denominada fase diplomática, é a etapa na qual serão desencadeados os diálogos pela busca de uma solução, devendo ser concluída no prazo de 15 (quinze) dias. Em caso de insucesso, iniciar-se-á o procedimento interventivo do Grupo Mercado Comum (GMC) e, em caso da inviabilidade de uma solução perdurar, dar-se-á início à etapa arbitral.

Sob a exegese do Protocolo de Brasília, as decisões proferidas pelo Tribunal arbitral eram inapeláveis e obrigatórias para os Estados-Partes. Observa-se o fato de a estrutura orgânica do Mercosul não contemplar um órgão de caráter jurisdicional instituído dentro do bloco. Sobre essa questão, o Protocolo nada estabelece, trazendo tão somente a duração de sua vigência, a saber, “[...] até que entre em vigor o Sistema permanente de solução de controvérsias." 13

Anexo ao Tratado Constitutivo do Mercosul que contemplava somente três órgãos, o Conselho Mercado Comum (CMC), o Grupo Mercado Comum (GMC) e a Comissão Parlamentar Conjunta, o Protocolo de Brasília trouxe um quarto órgão: a Secretaria Administrativa do Mercosul que é órgão vital para o bom funcionamento do Sistema de Solução de Controvérsias do Mercosul.

A possibilidade de o Sistema tratar das reclamações de particulares, pessoas físicas ou jurídicas também foi regulamentada no Anexo do Protocolo de Brasília.

Nesse sentido, o Regulamento do Protocolo de Brasília para Solução de Controvérsias dispõe que o objeto das controvérsias entre Estados, bem como das reclamações iniciadas a pedido de particulares, ficará determinado pelos textos de apresentação e de resposta, sem que possa ser feito posteriormente. ${ }^{14}$

No âmbito do Protocolo de Brasília e de seu Regulamento aprovado pela Decisão n. 17/98-CMC, foram emitidos dez laudos arbitrais.

\subsubsection{Protocolo de Ouro Preto}

O Protocolo de Ouro Preto, assinado em 17 de dezembro de 1994, foi criado pela necessidade de adaptação da estrutura institucional do Mercosul às mudanças

\footnotetext{
${ }^{13}$ Artigo 34 do PB.

${ }^{14}$ Artigo 28 do RegPB.
} 
advindas desde sua criação. ${ }^{15}$ Além disso, veio preencher algumas lacunas presentes no Tratado de Assunção, tal como o sistema de fontes jurídicas desse processo de integração. ${ }^{16}$

Em relação ao Protocolo de Brasília, que conformou a Secretaria Administrativa do bloco, o Protocolo de Ouro Preto veio expandir a estrutura do Mercosul por meio da criação da Comissão de Comércio, da Comissão Parlamentar Conjunta e do Foro Consultivo Econômico-Social. E ampliou a competência rationae materia do Sistema de Solução de Controvérsias, já que afora as matérias instituídas pelo Protocolo de Brasília, as Diretivas da Comissão de Comércio também passaram a fazer parte da normativa do Mercosul.

No documento foram estabelecidos os órgãos com capacidade decisória. O Conselho do Mercado Comum (CMC), o Grupo Mercado Comum (GMC) e a Comissão de Comércio do Mercosul (CCM $)^{17}$ são os órgãos competentes para a tomada de decisões que serão adotadas por consenso e com a presença de todos os membros. Além disso, ao Mercosul foi conferida personalidade jurídica de Direito Internacional. ${ }^{18}$

Por outro lado, como etapas paralelas do Sistema de Solução de Controvérsias, existem os procedimentos de Consultas e Reclamações, regulamentados pela Diretiva n. 17/99-CMC, no Anexo do Protocolo de Ouro Preto e na Decisão n. 18/02-CMC, respectivamente. Tais mecanismos ficam sob a gestão da Comissão de Comércio do Mercosul e do Grupo Mercado Comum.

O Anexo do Protocolo de Ouro Preto regulamenta o procedimento geral para as reclamações perante a Co-

\footnotetext{
${ }^{15}$ Sobre as mudanças advindas desde a criação do Mercosul, v. o artigo do autor: FONTOURA, Jorge. A revisão institucional do Mercosul: Ouro Preto II. Revista de estudos europeus, Coimbra, v. 1, n. 1, p. 291-297, jan./jun. 2007.

${ }^{16}$ PUÑAL, Antonio Martinez. O sistema de fontes do Mercosul: problemas normativos e bases para a resolução. Scientia Ivridica, Braga, Tomo LVI, n. 312, p. 670, out./nov. 2007.

${ }^{17}$ Artigo $2^{\circ}$ do Protocolo de Ouro Preto (POP).

${ }^{18}$ Artigo 37 do POP. Sobre a personalidade jurídica de Direito Internacional, Manuel Diez de, VELLASCO, Manuel Diez de. Las organizaciones internacionales. Madrid: Tecnos, 1999. p. 61-62, ponto 4, considera que o sujeito de personalidade jurídica internacional capacita-se, portanto, para ser titular de direitos e obrigações na ordem jurídica internacional, assim como o possibilita fazer valer internacionalmente esses direitos e de responder também internacionalmente em caso de violação dessas obrigações.
}

missão de Comércio do bloco (CCM), que por sua vez serão encaminhadas ao Conselho técnico, que terá o prazo de 30 (trinta) dias para que emita seu parecer. As reclamações, atendendo ao trâmite estabelecido no anexo, serão concluídas pela CCM na primeira reunião ordinária após o parecer conjunto ou as conclusões dos especialistas serem recebidos. Em caso de dissenso, as reclamações são remetidas ao Grupo Mercado Comum, que se pronunciará no mesmo prazo referido contado do recebimento. Não sendo alcançada uma conclusão satisfatória, o Estado reclamante poderá iniciar o procedimento arbitral estabelecido no Protocolo de Olivos, como veremos no ponto seguinte.

\subsubsection{O protocolo de Olivos ${ }^{19}$}

Assinado em 18 de fevereiro de 2002, o Protocolo de Olivos vem reconhecer que a evolução do processo de integração no âmbito do Mercosul requer o aperfeiçoamento do Sistema de Solução de Controvérsias. Dessa forma, vem trazer algumas inovações e resolver algumas lacunas existentes no Protocolo de Brasília, já derrogado, visando o amadurecimento do Sistema no que toca à eficiência da resolução de litígios. ${ }^{20}$

A evolução das diversas frentes de atuação e da vultosa gama de atividades que o Mercosul passou a desempenhar impulsionou a necessidade de elaboração de um Sistema mais completo, e como em diversas oportunidades o próprio bloco deixa claro, o SSCM encontra-se em constante aperfeiçoamento. ${ }^{21}$

O Protocolo de Olivos inicialmente estabelece seu âmbito de competência, que tocará essencialmente às controvérsias entre Estados quando relacionadas “[...] à interpretação, aplicação ou o não cumprimento do Tratado de Assunção, do Protocolo de Ouro Preto, dos protocolos e acordos celebrados no marco do Tratado de As-

${ }^{19} \mathrm{O}$ Protocolo de Olivos poderá ser mencionado no presente artigo sob a sigla PO.

${ }^{20}$ Sobre as alterações empreendidas a partir da entrada em vigor do Protocolo de Olivos, v. o artigo do Prof. Eduardo Biacchi Gomes. GOMES, Eduardo Biacchi. O Protocolo de Olivos: alterações no Sistema de Solução de Controvérsias do Mercosul e perspectivas. Revista da Faculdade de Direito, Curitiba, v. 37, p. 157-167, Jan. 2002.

${ }^{21}$ O Artigo 53 PO estabelece a revisão do Sistema, nestes termos: "Antes de finalizar o processo de convergência do Mercado Comum, os Estados-Partes efetuarão uma revisão do atual Sistema de Solução de Controvérsias a fim de adotar um Sistema Permanente de Solução de Controvérsias." 
sunção, das Decisões do CMC, das Resoluções do GMC e das Diretivas da CCM."22

A possibilidade de escolha do foro para a solução de controvérsias é a primeira inovação do documento. ${ }^{23}$ As partes são livres para escolha do foro, entretanto uma vez iniciado o procedimento, nenhuma das partes poderá optar por mecanismo diverso quando se tratar de mesmo objeto. Dessa forma, pode-se considerar que ao foro escolhido é atribuída competência exclusiva em razão do objeto. Alerta-se, no entanto, que a vedação estabelecida no Protocolo de Olivos refere-se às ações simultâneas em foros diferentes. Portanto, esta só se aplicará quando estiver diante de foros concomitantes. Nada impedindo que uma vez esgotado o litígio num foro, outro seja acionado. ${ }^{24}$

A adoção de mecanismos relativos aos aspectos técnicos cabíveis nos casos de divergência entre Estados sobre tais aspectos regulados em instrumentos de políticas comerciais comuns vem conferir maior celeridade na resolução de questões que envolvam mera engenharia e não requerem mais do que simples ajustes é a segunda inovação trazida com o Protocolo de Olivos. ${ }^{25}$

No tocante às fases que compreendem o SSCM, o Protocolo de Olivos estabelece-as. Com a ressalva que, de forma impreterível, a controvérsia seja iniciada pelas negociações diretas.

\subsubsection{Fase conciliatória}

Para que seja iniciada, a negociação direta tem o início de contagem do prazo, cujo trâmite não poderá exceder o prazo de 15 (quinze) dias contados a partir da data em que uma parte comunicou a outra da decisão de

${ }^{22}$ Artigo $1^{\circ}$, n.1 do PO.

${ }^{23}$ Artigo $1^{\circ}$, n.2 do PO.

${ }^{24}$ ACCIOLY, Elizabeth. O Atual mecanismo de solução de controvérsias do Mercosul: o Protocolo de Olivos. Revista da Faculdade de Direito, Lisboa, v. XLV, n. 13, p. 206, Jan 2004. A autora posiciona-se no sentido da iminência de decisões divergentes, de modo que a referida inovação poderia debilitar o Sistema de Solução de Controvérsias do Mercosul.

${ }^{25}$ Artigo $2^{\circ}$ do PO trata dos mecanismos relativos a aspectos técnicos. O n. 2 do mesmo artigo dispõe que os referidos mecanismos serão estabelecidos quando necessários e que as regras de funcionamento, seu alcance e a natureza dos pronunciamentos a serem emitidos serão definidas e aprovadas por Decisão do Conselho do Mercado Comum. iniciá-la. ${ }^{26}$ Observa-se, no entanto que o momento de início das negociações é muito mais claro do que o previsto no já derrogado Protocolo de Brasília. ${ }^{27}$

A controvérsia que não logrou êxito ou que não tenha alcançado um acordo de forma parcial na fase das negociações poderá ser levada à intervenção do GMC. No entanto, essa fase vem contemplada no $\mathrm{PO}$ com a possibilidade de ser suprimida.

As partes poderão levar a controvérsia diretamente ao procedimento arbitral. Logo, por vontade das partes, a fase conciliatória poderá ser dispensada. ${ }^{28} \mathrm{O}$ caráter optativo dessa fase se justifica pela urgência na adoção das medidas e na resolução do impasse. Ressalta-se que o Protocolo de Brasília já conferia uma brecha a uma interpretação flexível..$^{29}$ No entanto, se as partes optarem por manter a fase interventiva, tal procedimento não poderá exceder o prazo de 30 (trinta) dias a partir da data em que as partes se reuniram submetendo a controvérsia ao Grupo Mercado Comum, que, por sua vez, formulará recomendações aos Estados-Partes. ${ }^{30}$

A possibilidade de um terceiro Estado alheio à relação conflituosa proceder às devidas justificativas ao término das negociações diretas, e assim estar apto a levar a controvérsia à consideração do GMC, é uma inovação do Protocolo de Olivos. Diante da intervenção de terceiros, o procedimento arbitral iniciado pelo Estado demandante segue seu curso normal, salvo se houver acordo entre as partes na controvérsia. ${ }^{31}$

${ }^{26}$ Artigo $5^{\circ}$ n.1 do PO. As partes também deverão comunicar ao Grupo Mercado Comum por intermédio da Secretaria do Mercosul o andamento das negociações como dispõe o n. 2 do mesmo artigo.

${ }^{27}$ O Protocolo de Brasília sobre solução de controvérsias em seu artigo $3^{\circ}$ n. 2 dispunha que “[...] as negociações não poderão exceder o prazo de quinze dias, salvo acordo entre as partes, a partir da data em que um dos Estados- partes levantar a controvérsia."

${ }^{28}$ Artigo $6^{\circ}$ n.1 do PO.

${ }^{29} \mathrm{Na}$ expressão "poderá" disposta no artigo $4^{\circ}$ inciso I do Protocolo de Brasília presume-se certa flexibilidade para que as partes possam optar pela manutenção ou supressão da fase.

${ }^{30}$ Artigo $8^{\circ}$ do PO não traz diferença substancial ao disposto no PB.

${ }^{31}$ Artigo $6^{\circ}$, n. 3 do $\mathrm{PO} \mathrm{c/c}$ artigo $7^{\circ}$, n.3. Analogicamente o referido Estado exerceria o papel de Terceiro interveniente no Processo Civil brasileiro, alheio a relação em causa, mas interessado em questões trazidas na lide. 


\subsubsection{Fase arbitral}

A fase arbitral ${ }^{32}$ deve ser antecedida da comunicação das partes sobre a decisão de iniciá-lo. Considerando que o Protocolo de Brasília dispunha sobre a intenção das partes em recorrer à arbitragem, consideramos mais coerente, apesar de ser uma alteração sutil, o texto introduzido com o advento do Protocolo de Olivos. Diante desse instrumento, as partes decidem, enquanto que, no texto derrogado, as partes intentam fato que remetia à ideia de planejamento ou pretensão. Portanto, dar início ao procedimento arbitral é decisão entre as partes. ${ }^{33}$

A Composição do Tribunal arbitral ad hoc, por sua vez, não guarda mudanças em relação ao estabelecido no Protocolo de Brasília, exceto pela ampliação do número de árbitros. Cada Estado designará um árbitro, dos 12 (doze) titulares constantes na lista registrada junto a Secretaria Administrativa, no prazo de 15 (quinze) dias contados da data em que a Secretaria comunicou aos Estados a decisão de um deles recorrer à arbitragem. Sublinhando que, sob o Protocolo de Brasília, a lista era composta de dez árbitros. Logo, esse número é ampliado sob o novo regime. ${ }^{34}$

Cabe ressaltar as hipóteses de impedimentos quanto à designação de árbitros. ${ }^{35} \mathrm{O}$ Protocolo de Olivos prevê que o Estado designe na mesma lista de nomes um árbitro suplente em caso de incapacidade ou escusa do titular. Logo, se uma das partes não tiver realizado a escolha, será feita por sorteio pela Secretaria Administrativa no prazo de 2 (dois) dias.

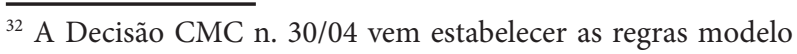
de procedimento para os tribunais arbitrais. MERCOSUR. Dec. CMC n. 30/04. Disponível em: <http://www.mercosur. int/innovaportal/v/580/1/secretaria/decisiones_2004> Acesso em: 07 Abr. 2012.

${ }^{33}$ Artigo 9, n.1 do PO.

${ }^{34}$ Artigo 11, n.1 do PO em referência ao artigo 10 do PB.

${ }^{35} \mathrm{O}$ regulamento do $\mathrm{PO}$ artigo $1^{\circ}$ dispõe sobre os casos de impedimento na designação do árbitro. Pessoas que se encontrem intervindo como representante de algum Estado-Parte na controvérsia, nas etapas prévias ao procedimento arbitral em matérias relacionadas ao objeto da controvérsia; que tenham interesse direto no objeto da controvérsia ou em seu resultado; que esteja representando ou que tenha representado durante qualquer período dos últimos três anos pessoas físicas ou jurídicas que tenham interesse na questão; ou que não tenha a necessária independência funcional da Administração Pública Central ou direta dos Estados- Partes na controvérsia estão impedidos de exercerem a função de árbitro.
O Protocolo de Olivos também estabelece o procedimento para nomeação do árbitro presidente e seu suplente, que atuará igualmente nos casos de impossibilidade ou escusa do titular. No entanto, nos casos em que não haja acordo quanto à nomeação de ambos, caberá à Secretaria proceder ao sorteio dos árbitros constantes na lista. Com a ressalva de que tanto o titular como o suplente não poderão ser nacionais dos Estados envolvidos na controvérsia e deverão se pronunciar sobre a aceitação da função no prazo de três dias.

Em relação à lista de árbitros, ${ }^{36}$ o Protocolo de Olivos estabelece que os Estados devem indicar 4 (quatro) integrantes para a lista de terceiros árbitros, devendo, nesse caso, ao menos um deles ser nacional de Estados terceiros. Os Estados poderão ainda pedir esclarecimentos e apresentar objeções aos nomes indicados na referida lista.

A possibilidade de representantes e assessores também se mantém inalterada, de modo que os Estados-Partes na controvérsia designarão representantes para o Tribunal ad hoc, podendo ainda designar assessores em suas defesas. Naqueles casos em que as partes sustentarem a mesma posição na controvérsia, poderão ser representadas conjuntamente, vindo a designar igualmente apenas um árbitro em comum acordo. ${ }^{37}$

O objeto da controvérsia não foi definido sob a vigência do Protocolo de Brasília. No entanto, segundo o Protocolo de Olivos (PO), o objeto será determinado nos textos de apresentação e de resposta apresentados ao Tribunal arbitral. ${ }^{38} \mathrm{O}$ PO salienta que mudanças de objeto ou sua complementaridade não poderão ser estabelecidas em outro momento. Desse modo, as alegações das partes constantes nos textos de apresentação e resposta serão

${ }^{36}$ ACCIOLY, Elizabeth. O Atual mecanismo de solução de controvérsias do Mercosul: o Protocolo de Olivos. Revista da Faculdade de Direito, Lisboa, v. XLV, n. 13, p. 211, Jan. 2004. $3^{\circ}$ parágrafo. A autora considera que a obrigatoriedade de se indicar árbitros de Estados terceiros em nada contribui para a resolução de litígios. Consideração entendida neste estudo como inequívoca se levarmos em conta a indicação de árbitros que atuem em mecanismos de blocos sob o regime supranacional e que não conheçam a fundo os ditames e implicações das decisões decorrentes de um organismo eminentemente intergovernamental como o que estamos tratando.

${ }^{37}$ Artigo 12 e 13 do PO.

${ }^{38}$ Artigo 14 do PO. 
baseadas nas questões que foram consideradas nas etapas prévias, e no Anexo do Protocolo de Ouro Preto. ${ }^{39}$

As medidas provisórias, ${ }^{40}$ sob o escopo do Protocolo de Olivos, são mantidas em relação ao estabelecido no Protocolo anterior. Logo, as partes poderão solicitar ao Tribunal que avalie o risco de danos graves e irreparáveis a uma das partes na controvérsia. Quanto aos casos em que um laudo for objeto de Recurso de revisão, as medidas provisórias que não tenham sido deixadas sem efeito antes de sua emissão, manter-se-ão até o tratamento do tema na primeira reunião do Tribunal Permanente de Revisão, momento no qual se decidirá pela manutenção das referidas medidas ou a extinção delas.

\subsubsection{O Tribunal Permanente de Revisão: um novo contexto}

Mediante o advento do Protocolo de Olivos, foi possível dar mais um passo evolutivo no que concerne ao Sistema de Solução de Controvérsias do Mercosul. Por meio da Decisão n. 30/05-CMC, foi estabelecido o Regulamento do Tribunal Permanente de Revisão (TPR) como órgão constituído como instância jurisdicional. ${ }^{41}$

\subsubsection{Composição}

A Composição do Tribunal Permanente de Revisão é feita por cinco árbitros. ${ }^{42}$ Cabendo a cada um dos

${ }^{39}$ No laudo I de 28 de abril de 1999 emitido pelo Tribunal ad hoc, Argentina e Brasil são partes. A Argentina apresenta como objeto da controvérsia as Circulares no 37/97, 7/98 e 23/98 da República Federativa do Brasil por considerá-las incompatíveis com os compromissos estabelecidos no Tratado de Assunção e na Normativa do Mercosul. No entanto, o Tribunal decide excluir a Circular 23/98 do objeto da controvérsia, uma vez que ela não foi apresentada pela demandante nas etapas prévias ao Procedimento arbitral.

${ }^{40}$ Artigo 15 do PO.

${ }^{41}$ Artigo $2^{\circ}$ do RegPO.

${ }^{42}$ Artigo 18, n.1 do PO.

${ }^{43}$ Artigo 18, n.2 do PO. forma permanente para atuarem quando convocados. ${ }^{44}$ No entanto, a controvérsia que envolver 2 (dois) Estados será integrada por 3 (três) árbitros, dos quais 2 (dois) serão nacionais dos Estados envolvidos no litígio e o terceiro será designado mediante sorteio. No entanto, no caso de haver mais de dois Estados envolvidos, o Tribunal será integrado por cinco árbitros. ${ }^{45}$

Como já mencionamos, o Tribunal Permanente de Revisão agrega funções não antes desempenhadas por outro órgão do Mercosul. Essas atribuições corroboram a ideia de um Tribunal que vem suprir diversas lacunas, e seja por questões de economia institucional, ou por razões de natureza experimental, exerce importantes funções tanto no âmbito contencioso quanto consultivo.

\subsubsection{Funções do Tribunal Permanente de Revisão}

Até a criação do Tribunal Permanente de Revisão (TPR), sob o advento do Protocolo de Olivos, não era cabível recurso das decisões do Tribunal ad hoc. Este novo órgão poderá cumular 4 (quatro) funções, são elas: (i) emitir opiniões consultivas; (ii) atuar como instância revisora dos laudos do Tribunal arbitral $a d h o c$, ressalvados os casos em que sejam emitidos com base no Princípio ex aequo et bono; e (iii) funcionar como única instância em controvérsias e adotar medidas excepcionais de urgência.

\subsection{Emissão de opiniões consultivas}

A primeira delas é a função de emitir opiniões consultivas que correspondem ao mecanismo de aprecia-

\footnotetext{
${ }^{44}$ A Dec. n. 36/08 CMC vem renovar os membros que comporão o TPR. Nela houve a renovação da lista de árbitros de forma que atuarão como membros do TPR para o mandato de 15/12/2008 até 15/12/2010, os membros titulares: Dr. Carlos María Correa (Argentina); Dr. João Grandino Rodas (Brasil); Dr. Roberto Ruiz Díaz Labrano (Paraguai); Dr. Roberto Puceiro Ripoll (Uruguai); Suplentes: Dr. Marcelo Antonio Gottifredi (Argentina); Dr. Alberto do Amaral Júnior (Brasil); Dr. Carlos Sosa Jovellanos (Paraguai); Dr. Ricardo Olivera García (Uruguai) e o $5^{\circ}$ árbitro Jorge Luis Fontoura Nogueira. Anterior à atual designação, a lista de nomes ficou adstrita à Dec. n. 38/07 que renovou os mandatos designados sob a Dec. n. 26/04 CMC para compor o TPR. Sob a Decisão de 2007, a atuação dos árbitros do TPR era a seguinte: (Membros titulares) Dr. Nicolás Eduardo Becerra (Argentina); Dr. João Grandino Rodas (Brasil); Dr. Wilfrido Fernández de Brix (Paraguai); Dr. Roberto Puceito Ripoll (Uruguai). Suplentes: Dra. Susana Czar de Zalduendo (Argentina); Dra. Nádia de Araújo (Brasil); Dr. Hugo Estigarribia Gutiérrez (Paraguai); Dr. Ricardo Olivera (Uruguai) e o $5^{\circ}$ árbitro Dr. José Antonio Moreno Ruffinelli (Paraguai).

${ }^{45}$ Art. 20, n.1 e n. 2 do PO.
} 
ção das questões prejudiciais, possibilitando ao juiz nacional que resolva dúvidas que porventura surjam sobre a aplicabilidade da normativa do Mercosul. ${ }^{46}$

Nesse procedimento, deverão ser observados os sujeitos capazes de solicitar a opinião consultiva do Tribunal. O particular, ora pessoa jurídica, não poderá aceder diretamente ao TPR, devendo oferecer a demanda perante o Poder Judicial ou instância nacional competente para que conduzam o assunto à análise do Tribunal Permanente de Revisão. Portanto, competentes serão os tribunais nacionais ou o órgão competente na esfera interna para formular a solicitação de opinião consultiva ao Tribunal Permanente de Revisão. ${ }^{47}$

O TPR emitiu sua primeira opinião consultiva em 2007, formulada pela juíza da $1^{\text {a }}$ instância do Tribunal Cível e Comercial de Assunção no tocante à controvérsia entre uma empresa paraguaia e outra argentina. No entanto, cabe-nos sublinhar que os casos levados à consulta do Tribunal Permanente de Revisão não poderão tratar de direito material referente à demanda na jurisdição interna, uma vez que é competente para emitir opiniões consultivas "[...] sobre questões de interpretação jurídica da normativa do Mercosul sempre que se vinculem com

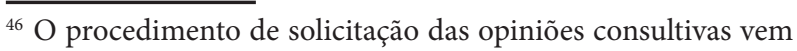
estabelecido na Dec. n. 02/07 do CMC.

${ }^{47}$ A Dec. n. 02/07 regulamenta o procedimento para a solicitação de opiniões consultivas ao TPR pelos Tribunais de justiça dos Estados-Membros, vem estabelecer que os órgãos nacionais capazes de cada Estado- parte para solicitarem opiniões consultivas são: Pela Republica Argentina, La Corte Suprema de Justicia de la Nación; pela República Federativa do Brasil, o Supremo Tribunal Federal; pela República do Paraguai, La Corte Suprema de Justicia; e pela República Oriental do Uruguai, La Suprema Corte de Justicia y Tribunal de lo Contencioso Administrativo. MERCOSUR. Dec. CMC n. 02/07. Disponível em: <http://www.mercosur.int/innovaportal/v/634/1/ secretaria/decisiones_2007>. Último acesso em: 07 Abr. 2012.

${ }^{47}$ Opinião Consultiva n. 1/2007 além de trazer aspectos de natureza procedimental no tocante às próprias atribuições do TPR vem igualmente demonstrar a cooperação existente entre o Tribunal Interno e o Tribunal Permanente de Revisão, que no caso referido acaba por falhar em virtude do desconhecimento do próprio juízo nacional paraguaio quanto aos procedimentos de solicitação. O Paraguai vem requerer da Argentina o pagamento de indenização por danos e prejuízos decorrente de responsabilidade contratual ante a Justiça Cível de Assunção, Paraguai. Entretanto, a Argentina vem alegar exceção de incompetência do Tribunal de $1^{\text {a }}$ instância de Assunção pelo disposto no Protocolo de Buenos Aires sobre jurisdição internacional em matéria contratual. No decorrer do procedimento, há, em prejuízo do Paraguai, a inoperância de remissão da solicitação até que o documento chegue às mãos do Tribunal Permanente de Revisão, uma vez que, passada a causas que estão sendo tramitadas no Poder judicial do Estado parte solicitante." 48

\subsection{Revisão dos laudos emitidos pelo Tribunal ad hoc}

O procedimento de revisão do laudo emitido pelo Tribunal ad hoc também é função do Tribunal Permanente, que receberá o Recurso de revisão impetrado por qualquer dos Estados-Partes na controvérsia em prazo não superior a 15 (quinze) dias, contados a partir de sua notificação, com limites restritos às questões de direito tratadas na controvérsia e às interpretações jurídicas desenvolvidas no laudo do Tribunal ad hoc (TAH). ${ }^{49}$

A contestação do Recurso de revisão pela outra parte na controvérsia é cabível no prazo de 15 (quinze) dias após sua notificação sobre a apresentação do recurso. $\mathrm{O}$ Tribunal Permanente de Revisão pronunciar-se-á sobre o recurso no prazo máximo de 30 (trinta) dias contados da apresentação da contestação. Esse prazo, no entanto, poderá ser prorrogado por outros 15 (quinze) dias.

\subsection{Adoção de medidas de urgência}

O Tribunal Permanente de Revisão também tem a incumbência de adotar medidas excepcionais de urgência. Além disso, o estabelecimento dos procedimentos especiais para atender os casos que requeiram a adoção de tais medidas ficará a cargo do Conselho do Mercado Comum..$^{50}$

decisão da magistrada em solicitar a opinião do TPR sobre a matéria que envolve o conflito de competências, esta remete a providência à Corte Suprema de Justiça, que, por sua vez, remete o documento ao Ministério das Relações Exteriores, o que demonstra a inabilidade e desconhecimento da Corte como órgão capaz de diretamente remeter á questão ao TPR. Além disso, por uma questão de ordem temporal, a solicitação acaba por ser recebida em momento anterior à entrada em vigor da Dec. CMC no 02/07, contrariando assim o estabelecido no artigo $4^{\circ}$, inciso 2 do Reg. PO.

${ }^{49}$ Artigo 17, n.1 e n. 2.

${ }^{50}$ A Dec. CMC n. 23/04 vem estabelecer o procedimento para solicitação dessas medidas pelos Estados- Partes, além de conceituar quais as situações excepcionais apresentadas para que a parte possa recorrer. Estabelece em seu artigo $2^{\circ}$ que as partes poderão recorrer ao TPR sempre que se apresentarem situações nas quais os bens sejam perecíveis, sazonais ou com curto tempo de vida, ou forem retidos injustificadamente no território do país reclamado; quando a situação se originar em ações ou medidas adotadas por um Estado-Parte em violação ou descumprimento à normativa do Mercosul; se a manutenção da situação implicar em danos graves e irreparáveis; e que as ações questionadas não sejam objeto de demanda em trâmite entre as partes envolvidas. MERCOSUR. Dec. CMC n. 23/04. Disponível em: http://www.mercosur.int/innovaportal/v/580/1/ secretaria/decisiones_2004. Acesso em: 07 Abr. 2012. 
Nesses casos, o julgamento das medidas deverá contar com a presença de todos os membros presentes nas etapas anteriores a esta e o deferimento da medida urgente deverá ser acompanhado da proporcionalidade com dano causado. ${ }^{51}$

O Protocolo de Olivos garante o acesso direto ao TPR. ${ }^{52}$ Logo, as partes poderão, após o esgotamento da fase de negociação, aceder diretamente e em única instância o Tribunal Permanente de Revisão (TPR). Dessa forma, podemos afirmar que o TPR terá as mesmas competências de um Tribunal ad hoc, porém, com o diferencial de ser um tribunal permanente criado no âmbito do Mercosul, e não formado temporariamente tão somente para a solução de um litígio específico.

Ao funcionar como primeira e única instância, seus laudos serão inapeláveis e obrigatórios para os Estados-Partes na controvérsia a partir do recebimento da respectiva notificação, e terão força de coisa julgada. ${ }^{53}$ Diante disso, o laudo emitido não estará, portanto, sujeito ao Recurso de revisão, tornando-se decisão definitiva em relação às partes.

O Protocolo de Olivos, por meio da criação do Tribunal Permanente de Revisão atribuiu a esse novo órgão uma importância maior do que o conferido aos Tribunais ad hoc, seja pela natureza que possui como órgão jurisdicional interno sem caráter temporário, seja pela possibilidade de as partes suprimirem a instância arbitral e levarem o conflito diretamente à sua apreciação.

O fato de o litígio ter a possibilidade de ser levado em única instância ao TPR, suprimindo a instância que de forma habitual desempenhava o papel julgador, torna a estrutura institucional do Mercosul mais sólida, uma vez que amplia sua orgânica por meio da criação de um tribunal permanente multifuncional que se ocupará de forma direta das demandas apresentadas pelos Estados, além de possuir um plus de em outra condição, poder atuar como órgão revisor, reservadas ainda suas duas outras funções já analisadas. Destarte, o objetivo do Mercosul com o Protocolo de Olivos - apesar de expressamente seu caráter transitório - é a evolução do Sistema de Solução de Controvérsias para um genuíno Tribunal, que se encontra atualmente em sua fase embrionária com a chegada do Tribunal Permanente de Revisão.

\footnotetext{
${ }^{51}$ A Dec. CMC n. 23/04, art. 4 c/c art.6.

${ }^{52}$ Art. 23, n.1 do PO.

${ }^{53}$ Art. 23, n. 2 do PO.
}

Para que o TPR venha a ser verdadeiramente consolidado como um Tribunal regional será necessário que algumas mudanças ocorram. Em primeiro lugar, deverá ser composto por juízes permanentes, e não por árbitros que atualmente compõem o Tribunal e devem estar disponíveis permanentemente para atuar quando convocados. Logo, observa-se que esta disponibilidade possibilita aos julgadores o exercício de funções autônomas, mas os obriga a estarem disponíveis para atuar a qualquer momento. Em segundo lugar, o Tribunal em formação deverá conter um corpo de magistrados permanentes, levando à composição de um quadro fixo de funcionários. No entanto, nada impede que este inclua juízes ad hoc. Em terceiro lugar, o Tribunal deverá desempenhar funções e possuir características inerentes à função judicial, formato que já existe atualmente no Mercosul. Em quarto lugar, o Tribunal deve ser assumido como jurisdição obrigatória dos Estados-Membros. E em quinto lugar, consideramos que o Tribunal regional não poderá escapar de uma atuação que inclua todos os países que tenham relações comerciais com os Estados- Membros do bloco. Logo, para que seja conformado, deverá haver uma ampliação em âmbito regional que favorecerá o acesso de outros Estados à jurisdição do Tribunal Permanente de Revisão, ainda que sob condições previamente fixadas. Atualmente, no entanto, verificamos um acesso exclusivo aos membros do bloco.

No tocante à situação dos particulares, talvez este fosse o ponto mais complexo e que, estima-se, poderia trazer certas limitações, já que o acesso aos tribunais internacionais de forma geral é bastante restrito. Os particulares vêm sendo beneficiados das decisões dos tribunais sobre a controvérsia envolvendo o Estado de que são cidadãos quando essas decisões são incorporadas ao ordenamento jurídico nacional deste Estado. Todavia, não poderão transpor as barreiras existentes nas normas de Direito Internacional e aceder ao Tribunal livremente, cabendo-lhes a tarefa restrita de observador do fiel cumprimento das decisões do Tribunal do Mercosul pelo Estado do qual é parte. ${ }^{54}$

\footnotetext{
${ }^{54}$ CAMINHA, Maria do Carmo Puccini. O acesso à jurisdição no espaço integrado do Mercosul. Revista da Faculdade de Direito, Coimbra, v. 43, n. 1, p. 562, Jan. 2002. A autora traça um comparativo entre o acesso do particular no TJUE e seu acesso às cortes internacionais que decidem somente litígios intergovernamentais.
} 
Atualmente, o Protocolo de Olivos ocupa seu Capítulo XI das reclamações de particulares, estabelecendo as matérias que poderão ser objeto de reclamações e o procedimento que as envolve. ${ }^{55}$ Todavia, verificando-se a procedência da reclamação e não sendo possível a resolução da questão, não será o particular (pessoa física ou jurídica), mas sim o Estado ou instituição que o representa quem terá competência para requerer a adoção de medidas corretivas ou anulatórias das medidas questionadas. Se, no entanto, expirado o prazo de 15 (quinze) dias o requerimento não lograr êxito, o Estado que o adotou poderá iniciar diretamente o procedimento arbitral.

Vislumbra-se diante desta questão que a atuação dos particulares já é limitada quando fica adstrita à formalização da reclamação junto à Secção Nacional do Grupo Mercado Comum (GMC) do Estado-Parte em que aquele reside ou tem a sede de sua empresa, não sendo cabível assim, transpor a barreira imposta pelas limitações existentes nas relações interestatais que, via de regra, regem os Tribunais regionais.

O Protocolo de Olivos vem tratar igualmente dos laudos arbitrais. Tanto os laudos do Tribunal ad hoc (TAH) quanto do Tribunal Permanente de Revisão serão adotados por maioria, devidamente fundamentados e assinados pelo presidente e pelos demais árbitros. Votos dissidentes não poderão ser fundamentados, preservando-se a confidencialidade da votação e das deliberações. ${ }^{56}$

Os laudos deverão ser decididos com base no Direito do Mercosul e nos princípios e disposições aplicáveis à matéria objeto da controvérsia, sendo possível ainda o julgamento com base na equidade ou ex aequo et bono, se as partes assim acordarem. Quando emitidos pelo Tribunal ad hoc, terão força de coisa julgada, se as partes não interpuserem o Recurso de revisão junto ao TPR. Caso seja interposto o recurso, da decisão proferida

\footnotetext{
${ }_{55}$ O procedimento cabível aos particulares vem regulamentado no artigo 39 e ss. O artigo 39 do PO estabelece que o objeto da demanda feita por particulares deverá versar sobre "[...] sanção ou aplicação, por qualquer dos Estados partes de medidas legais ou administrativas de efeito restritivo, discriminatório ou de concorrência desleal [...]." As reclamações deverão ser formalizadas na Seção Nacional do GMC do Estado -Parte em que tenha residência ou sede dos negócios, a qual deverá conter indícios de materialidade suficientes que permitam determinar sua procedência junto ao GMC e especialistas, se assim imperar.

${ }^{56}$ Artigo 25 do PO.
}

não caberá outro recurso, já que é inapelável, terá força de coisa julgada e será obrigatória para os Estados-Partes.

A possibilidade de qualquer dos Estados-Partes solicitarem Recurso de esclarecimento do laudo do Tribunal ad hoc ou do Tribunal Permanente de Revisão também é estabelecido no Protocolo de Olivos, podendo ser feita no prazo de 15 (quinze) dias subsequentes à sua notificação. ${ }^{57}$ Observa-se que o protocolo anterior não denominou o termo "recurso" para tratar dos casos de dúvidas ou esclarecimento de questões envolvendo o laudo. Logo, o Protocolo de Olivos o fez, designando como recurso a possibilidade da parte prejudicada ter suas dúvidas sanadas ou reparadas nos casos de omissão.

Sobre o prazo e modalidade de cumprimento do lau$\mathrm{do}^{58}$, a parte vencida deverá cumpri-lo no prazo de trinta dias seguintes à data de sua notificação, caso o Tribunal não fixe outro prazo. O Estado deverá informar no prazo de 15 (quinze) dias contados da sua notificação ao outro Estado na controvérsia e a Secretaria do Grupo Mercado Comum as medidas que resolveu adotar para dar cumprimento ao laudo. Mas, nos casos do Recurso de revisão oponível à decisão constante do laudo, o prazo para cumprimento será suspenso.

O Estado demandante que viu seu pleito favorável poderá entender que as medidas adotadas pela parte vencida não foram satisfatórias, divergindo assim sobre o cumprimento do laudo. Nesse caso, terá o prazo de 30 (trinta) dias para levar a questão ao Tribunal, que, por sua vez, terá o mesmo prazo para dirimir a questão. Todavia, se os mesmos juízes que conheceram o caso não puderem apreciar a questão, serão convocados seus suplentes ou outro Tribunal será formado. ${ }^{59}$

Há casos em que o Estado-Parte não cumpre o laudo ou o cumpre apenas de forma parcial. Nessa situação, o Estado beneficiado da decisão poderá adotar medidas como forma de coerção para que aquele Estado cumpra o laudo, já que possui a faculdade - dentro do prazo de um 1 (ano) contados do dia em que expirou o prazo fixado para cumprimento - de iniciar a aplicação de medidas compensatórias temporárias que cessarão no momento em que a parte cumprir a decisão proferida. ${ }^{60}$

\footnotetext{
${ }^{57}$ Artigo 28 do PO.

${ }^{58}$ Artigo 29, n. 1, 3 e 2, respectivamente do PO.

${ }^{59}$ Artigo 30 n. 1, 2 e 3 do PO.

${ }^{60}$ Não poderíamos deixar de considerar que as medidas compensatórias têm respaldo dos Princípios da Reciprocidade e no Princípio pacta sunt servanda que regem o Direito Internacional Público.
} 
A medida compensatória é uma forma de represália adotada nos casos de não cumprimento do laudo. Porém, não poderá ser adotada de forma desarrazoada e indiscriminada, especialmente por dever ter conta a proporcionalidade. Logo, deverá incidir primeiramente sobre a suspensão de concessões ou obrigações equivalentes no mesmo setor ou setores afetados. E pensando nessa questão, o Protocolo de Olivos estabeleceu a faculdade de questionamento das medidas provisórias, levando ao questionamento sobre a medida ter sido ou não adotada de forma harmoniosa ou discrepante a fim de evitar possíveis abusos. ${ }^{61}$

\subsection{Funcionamento do sistema: controvérsia entre república oriental do Uruguai e república Argentina sobre a proibição de importação de pneus reconstituídos}

O Sistema de Solução de Controvérsias do Mercosul (SSCM) tem evoluído prioritariamente por meio de suas decisões. E em um processo evolutivo como se encontra o Mercosul, podem ser considerados elementos de peso no desenvolvimento do Sistema para um ideal que atenda as aspirações dos seus Estados-Membros. Na realidade, não é esse o propósito principal do Sistema, e seria muito simplista se assim o fosse.

O SSCM visa à resolução de um litígio que envolve aspectos muito mais amplos do que a mera satisfação de uma das partes. Nasce do compromisso de manutenção das relações entre os Estados em face dos objetivos que perquire o Mercosul. E a responsabilidade de sua evolução, diante do que pudemos observar neste artigo, envolve principalmente alguns fatores, tais como: (i) uma normativa que seja completa nos ideais que busca o Mercosul e seu Tratado constitutivo; (ii) que esta normativa abarque as matérias que sejam levadas ao Tribunal pelos

\footnotetext{
${ }^{61}$ Artigo 32 do PO estabelece a possibilidade de questionar as medidas provisórias, de modo que o Estado não cumpridor do laudo, que considere ter adotado as medidas de forma satisfatória, terá o prazo de quinze dias para levar a questão ao Tribunal, contados da apresentação das medidas que serão adotadas. O Estado não cumpridor do laudo poderá considerar excessivas as medidas compensatórias aplicadas. Assim, no prazo de quinze dias após a aplicação das referidas medidas, poderá solicitar que o Tribunal se pronuncie a respeito no prazo de trinta dias. Ele, ao analisar as medidas, considerará alguns elementos, dentre eles a dimensão afetada no mercado interno daquele Estado, de modo que, ao verificar que houve excesso, exigirá que o Estado proceda à adequação no prazo de dez dias.
}

Estados; e (iii) que o intérprete dessa normativa tenha um compromisso em reafirmá-la como aplicável e ainda que a mesma silencie sob algumas questões, é função do Tribunal constituído adotar os critérios mais equilibrados para resolver o impasse.

O próprio Tribunal ad hoc já assumiu em seu laudo inaugural que:

[...] terá de buscar e identificar regras jurídicas aplicáveis, guiado pelos fins e objetivos de ordem normativa criado pelas partes, sendo o próprio Tribunal um elemento do ordenamento que as partes conformaram para regular suas relações recíprocas com vistas a alcançar o objetivo compartilhado de sua integração, no âmbito dos fins e princípios do sistema do Tratado de Assunção. ${ }^{62}$

A longa controvérsia que se apresenta evolve o Uruguai e a Argentina, respectivamente demandante e demandada no impasse que reside na Lei 25.656 promulgada pela Argentina, proibindo a importação de pneus reconstituídos. $\mathrm{O}$ caso possui cinco fases, quais sejam: (i) as negociações diretas; (ii) o procedimento ad hoc; (iii) o procedimento de revisão; (iv) o recurso de esclarecimento; e (v) o questionamento das medidas compensatórias e o pronunciamento sobre o excesso de tais medidas.

\subsubsection{Negociações diretas}

A Argentina promulgou a Lei 25.626 que proíbe a importação de pneus reconstituídos, produto que o Uruguai fabrica e que ocupa boa parcela de suas exportações. Por essa razão, o Uruguai comunica à Argentina sua decisão de dar início ao litígio. ${ }^{63} \mathrm{~A}$ Argentina propôs um acordo de equilíbrio entre os dois países que levaria a redução inexpressiva das importações. Além disso, propôs ao Uruguai que passasse a importar os pneus argentinos, reconstituindo-os em seu território e os exportando de volta para aquele país. No entanto, em virtude do insucesso dessa fase preliminar, o Uruguai transmite à Secretaria do Mercosul sua decisão de recorrer ao Procedimento arbitral. E, por questões de celeridade processual e de que a demora de uma solução viesse a acarretar maiores prejuízos ao setor afetado, o Uruguai vem suprimir, e assim lhe é facultado, a fase conciliatória sob a intervenção do Grupo Mercado Comum (GMC).

\footnotetext{
${ }^{62}$ Laudo n. 1/1999, considerando 51.

${ }^{63}$ A proposta do Uruguai em dar início à Negociação Coletiva ocorre em 06/12/2004, e a resposta da Argentina em concordância com a questão é dada em 10/12/2004.
} 


\subsubsection{Procedimento arbitral}

Um dos fatores pelo qual as partes convencionaram submeter suas controvérsias à arbitragem é a maior simplicidade com que se desenvolve o procedimento e a celeridade na obtenção de uma decisão. Ainda que o Protocolo de Olivos possibilite a prorrogação do prazo para emissão do laudo pelo prazo superior a 30 (trinta) dias, o procedimento arbitral mostra-se rápido e dinâmico. ${ }^{64}$

Nesse procedimento que envolve Uruguai e Argentina, algumas formalidades necessárias devem ser atendidas. O local da arbitragem é definido como Montevidéu, logo as partes devem fixar residência no local acordado; o Tribunal designa os árbitros que comporão o procedimento; informa às partes do local designado com antecedência de 15 (quinze dias), além de esclarecer as regras do procedimento previstas na Dec. n. 30/04 do CMC e no Regulamento do Protocolo de Olivos. ${ }^{65}$

A parte demandante apresentará suas razões por meio de um texto escrito contendo principalmente os fatos, atos, omissões ou medidas para fins de delimitação do objeto da controvérsia. Além disso, deverá expor o direito em que se baseia a demanda; a prova documental que se acompanha e outros meios de prova oferecidos e a petição. ${ }^{66}$

O momento de apresentação da peça processual pela parte demandante e de resposta da parte demandada é aquele em que oportunamente os Estados-Partes apresentarão o objeto da controvérsia. Logo, caso sejam

\footnotetext{
${ }^{64}$ A emissão dos laudos pelo Tribunal Arbitral ad hoc será realizada atendido o prazo de sessenta dias, prorrogáveis por no máximo trinta dias; O Laudo n. 1/1999 cuja controvérsia envolveu Argentina e Brasil, o árbitro presidente foi notificado de sua atuação em 29 de janeiro de 1999 e a decisão foi prolatada em 28 de abril de 1999, ou seja, apenas 3 (três) meses depois da notificação.

${ }^{65}$ Laudo 1/1999. Foram constituídos os seguintes árbitros para o procedimento arbitral: Dr. Hermes Marcelo Huck, da República Federativa do Brasil, Dr. José Gamio da República Oriental do Uruguai e Dr. Marcelo Antonio Gottifredi, da República Argentina.

${ }^{66}$ Dec. CMC n. 30/04 Artigo $13 \mathrm{c} / \mathrm{c}$ artigo 27 do PO. As provas deverão ser anexadas juntamente com o texto inicial apresentado pelo Uruguai e na contestação feita pela Argentina. O demandante acaba por designar prova pericial que venha a apresentar detalhes técnicos sobre a produção de pneus reconstruídos, e será ouvido em audiência. Esta ademais será dividida em duas sessões: uma para oitiva de testemunhas e outra para apresentação da posição das partes. As alegações finais, no entanto serão apresentadas no prazo de sete dias posteriores às audiências.
}

apresentados outros fatos em momento diverso, serão rejeitados pelo Tribunal. ${ }^{67}$ Ademais, nos casos em que o objeto for conhecido nas etapas prévias à arbitragem, não poderá ser alterado em face do Tribunal ad hoc..$^{68}$

O Estado-Parte demandante sustenta suas alegações com base no caráter inibidor e violador do livre comércio subscrito na Lei argentina, além de alegar que tal postura é contraria ao Princípio do tratamento igualitário em relação aos pneus por ele exportados, especialmente quando aquela continua a importar o produto de outros países. Segundo o Uruguai, há violação do Tratado de Assunção e seu Anexo, das Decisões do Conselho Mercado Comum sobre acesso aos mercados e igualmente dos Princípios de Direito Internacional Público como direito aplicável ao caso ${ }^{69}$ Segundo o Uruguai, o conteúdo da Lei argentina é contrário às normas do Mercosul, na medida em que restringe injustamente o comércio, interrompendo o fluxo comercial de pneus produzidos que eram exportados pela demandante.

A Argentina por sua vez apresenta sua contestação dentro do prazo determinado. ${ }^{70}$ Com o destaque de que sua resposta deverá conter principalmente os antecedentes da controvérsia, os fundamentos de sua defesa, os fatos e o direito invocado; a prova documental anexada e outros meios de prova oferecidos; e a petição ${ }^{71}$. Destarte, alega que rejeita a amplitude do pedido feito pelo Uru-

${ }^{67}$ Laudo n. 1/1999, considerando 24. A Argentina vem apresentar um dos objetos da controvérsia na demanda contra o Brasil fora do momento de apresentação, de modo que o Tribunal vem se pronunciar nestes termos: "[...] o objeto da reclamação é unicamente as Circulares no 37/97 e 7/98, não devendo considerar-se nenhum fato ou argumento relacionado ao comunicado 23/98, instrumento que não constava nos termos originais da reclamação."

${ }^{68}$ Laudo n. $2 / 1999$, controvérsia entre Argentina e Brasil sobre subsídios à produção e exportação da carne de cerdo. $\mathrm{O}$ Tribunal vem considerar a inalterabilidade do objeto a partir de sua delimitação. Nesse caso, o objeto da controvérsia foi conhecido na etapa de negociações diretas, nos seguintes termos: "Si el objeto de la controversia ha quedado fijado en la etapa de negociaciones diplomáticas, a partir de entonces ya no puede haber modificación del objeto de la litis por las partes involucradas", p. 15-16, considerando 44.

${ }^{69} \mathrm{O}$ Uruguai alega violação aos artigos $1^{\circ}$ e $5^{\circ}$ do TA e seu Anexo I; violação às Decisões do CMC n. 22/00 e n. 57/00 relativas ao Acesso a mercados; e aos Princípios de Direito Internacional Público, tais como pacta sunt servanda, boa fé consagrado na Convenção de Viena em seu artigo 26 e ao Princípio de Estoppel.

${ }^{70}$ Dec. CMC n. 30/04, artigo 14, caput. A decisão estabelece que o prazo para apresentação de resposta é de 20 (vinte) dias.

${ }^{71}$ Dec. CMC n. 30/04, artigo 14, letras c, d e f. 
guai por considerá-lo genérico, não específico e abstrato. E que a referida Lei é medida de caráter preventivo destinada a evitar dano potencial ao meio ambiente, configurando-se como exceção ao Princípio do livre comércio fundamentado no Tratado de Montevidéu em seu artigo 50 e incorporado ao Tratado de Assunção. Ainda argumenta que a Lei é compatível com as normas do Mercosul, proporcional e não discriminatória, já que desde 2001 o país não importa nenhum pneu reconstituído.

Sobre a amplitude do objeto, o Tribunal adota uma postura preventiva ao considerar que este não poderá resumir-se na Lei em si, mas deverá abarcar seu conteúdo. Considerando, assim, que essa Lei não deverá ser analisada sob seu ponto de vista formal, mas sim sob o prisma de seu conteúdo e do impacto desse conteúdo sobre o comércio bilateral das partes. ${ }^{72}$ Esse critério adotado pelo Tribunal se justifica pelo fato de que, ao incidir unicamente sobre a Lei, haveria riscos caso ela fosse derrogada e no seu lugar editado outro ato normativo de igual teor e conteúdo. ${ }^{73}$

Além disso, o pedido que objeta a parte reclamante não poderá ser genérico, devendo ser certo e determinado. No entanto, isso não impede que o Tribunal ad hoc decida de forma congruente à consideração feita pelo Uruguai ao alegar que o objeto da controvérsia é a proibição de importação de pneus reconstituídos positivada pela Lei 25.626 de 2002 da República da Argentina e qualquer outro texto legislativo ou administrativo que tenha ou venha a ter na prática os mesmos efeitos da citada Lei. ${ }^{74}$ Ressalta-se que esta colocação pode estar dotada de erro, já que sendo o objeto certo e determinando, ele não poderia incluir outras questões que fossem apresentadas pela reclamante de forma ampla e genérica.

Da mesma forma, a definição do objeto deve estar condicionada à sua incompatibilidade perante a normativa do Mercosul. No caso da Lei 25.626, promulgada pela Argentina em 08 de agosto de 2002, compete ao Tribunal verificar sua congruência com os direitos vetores do Mercosul e com as normas de Direito Internacional que se apliquem ao caso concreto. $O$ Tribunal conclui que houve confronto entre o Princípio da livre circulação de

\footnotetext{
${ }_{72}$ Laudo arbitral de 25 de outubro de 2005, considerando 88 .

${ }^{73}$ Laudo arbitral de 25 de outubro de 2005, considerando 88 .

${ }^{74}$ Laudo arbitral de 25 de outubro de 2005, considerando 90.
}

mercadorias sustentado no banimento de barreiras não econômicas ao comércio entre os Estados-Membros e nas normas que garantem a preservação ambiental, da saúde das pessoas, animais e vegetais da zona. ${ }^{75}$

Quanto à normativa aplicável ao caso, para o Tribunal, não resta dúvida de que é o Direito do Mercosul. No entanto, sobre os dois pontos alegados pela Argentina no tocante à exceção ao Principio de livre comércio, são eles: a segurança dos pneus reconstituídos e a proteção ambiental, o Tribunal decide que os referidos pneus provocam dano ambiental depois de esgotado seu tempo de vida útil, mas são seguros.

O Tribunal parte da premissa de que a liberdade comercial é princípio base da integração mercosulina e não poderá ser compreendida de forma absoluta, já que existem questões de caráter primordial que devem ser excepcionadas à sua prevalência, nas quais se enquadram os riscos ao meio ambiente. Diante disso, considera que há compatibilidade da Lei argentina em relação aos Princípios norteadores do Mercosul sem fazer menção a nenhum outro aspecto de caráter material.

\subsubsection{Procedimento de revisão}

A possibilidade de interpor o Recurso de revisão confere ao Estado prejudicado com a decisão do Tribunal ad hoc o direito de requerer a revisão do laudo emitido.

Sob o Laudo n. 1/2005, ${ }^{76}$ o Tribunal Permanente de Revisão emitiu seu primeiro entendimento sobre a decisão arbitral envolvendo Uruguai e Argentina. ${ }^{77}$ Os representantes de ambas as partes foram designados e seus domicílios constituídos. Além de que as regras de procedimento foram estabelecidas e os árbitros que atuarão

\footnotetext{
${ }^{75}$ Laudo arbitral de 25 de outubro de 2005, considerando 47.

${ }^{76}$ Laudo emitido em 20 de dezembro de 2005.

${ }^{77} \mathrm{O}$ Uruguai veio apresentar o Recurso de Revisão em 9 de novembro de 2005 e um mês depois foi contestado pela Argentina, de modo que esse país não atendeu ao prazo estabelecido na Dec. CMC n. 30/05. A Dec. CMC n. 30/05 que cuida do procedimento do TPR é clara em seu artigo $18,1^{\text {a }}$ parte ao estabelecer que o prazo para resposta da parte recorrida seja de 15 dias. No entanto, não consta no laudo se houve ou não algum pedido de prorrogação por parte da Argentina, o que é cabível segundo o artigo 16, b. De qualquer forma, o procedimento segue seu curso. MERCOSUR. Dec. CMC n. 30/05. Disponível em: < http://www.mercosur.int/ innovaportal/v/1066/1/secretaria/decisiones_2005>. Acesso em: 07 Abr. 2012.
} 
foram designados. ${ }^{78}$ Em seguida, o Tribunal convocou audiência oral para oitiva das partes.

O Recurso de revisão não vem expor fato novo, mas sim realizar uma análise atenta às questões de direito e às interpretações do laudo emitido pelo Tribunal ad hoc. Desse modo, analisa o objeto da controvérsia definido pelo Tribunal arbitral e seu conteúdo. E, contrariando a conclusão do Tribunal ad hoc pela amplitude do objeto que abarca não apenas a Lei argentina em questão e seu conteúdo, mas também outros atos ou normas de igual teor, o Tribunal Permanente de Revisão considera que o referido objeto não poderá ser amplo ao ponto de incluir “[...] todo texto legislativo ou administrativo que a Argentina tenha ou venha ter com os mesmos efeitos [...] uma vez que vigoram os Princípios da especificidade e da não abstração que devem primar em toda pretensão litigiosa em concreto." ${ }^{39}$

O Tribunal admite que o Princípio do livre comércio não é uma questão jurídica controvertida. Logo, em desconformidade com a análise antecedida pelo Tribunal ad hoc, o Tribunal Permanente de Revisão considera que esse Princípio foi estabelecido de forma clara pela normativa do Mercosul e que as exceções existentes não se aplicam ao caso em questão.

O laudo corrige a alegação argentina em algumas passagens de sua contestação nas quais menciona o Tratado de Montevidéu (TM) de 1950, quando, na realidade, ele foi firmado em 1980. Além disso, o Tribunal considera que a normativa aludida pela Argentina deve ser interpretada corretamente, já que o artigo 50 do TM foi incorporado ao Anexo do Tratado de Assunção em seu artigo $2^{\circ}$, letra b e não subscreve exceção cabível ao livre comércio corporificado na vedação à importação de pneus reconstituídos.

O Tribunal Permanente de Revisão discorda da análise adotada pelo Tribunal ad hoc ao considerar que

\footnotetext{
${ }^{78}$ As regras de procedimento são definidas como a Dec. n. 30/05 CMC; os árbitros que atuaram no procedimento de revisão foram: Dr. Nicolas Eduardo Becerra (Argentina); Ricardo Oliveira (Uruguai) e o árbitro presidente Dr. Wilfrido Fernández (Paraguai), atendendo, portanto, à designação estabelecida no PO, em seu art. 20, que estabelece: quando a controvérsia envolver 2 (dois) Estados-Partes, o TPR estará integrado por 3 (três) árbitros, dos quais 2 (dois) serão nacionais de cada Estado-Parte na controvérsia e o terceiro, que exercerá a presidência, será designado mediante sorteio

${ }^{79}$ Laudo n. 1/2005, considerando 24.
}

não há colisão entre o Princípio do livre comércio e o Princípio da proteção do meio ambiente, mas sim a violação do primeiro e a existência do segundo como sua possível exceção. No entanto, sobre o elemento excepcionado, o TPR reconhece que o Mercosul carece de um corpo legal que estabeleça clara e concretamente os critérios de rigor a serem analisados para invocação de tais exceções. ${ }^{80}$ Considera igualmente que o TAH errou em não detalhar os critérios que o levaram a considerar a exceção ao Princípio de livre comércio em face da ausência normativa do Mercosul nessa matéria específica.

O Tribunal faz questão de expor que a exceção discutida, ainda que esteja ausente de forma específica nas normas reguladoras do Mercosul, deve ser observada sob o prisma do Protocolo de Olivos e não das normas gerais de Direito Internacional. Logo, reconhece que as normas de Direito Internacional Público estão incorporadas ao Protocolo de Olivos e devem ser invocadas de forma subsidiária, e apenas quando versarem sobre a matéria objetada no caso concreto.

O Tribunal Permanente de Revisão atua pela primeira vez na revisão de um laudo arbitral e não foram estabelecidos critérios em decisões anteriores que tornassem possível a extração de meios que facilitassem sua atuação. Seja pela ausência de maior detalhismo na busca de uma solução, seja pelo número irrisório de decisões - especialmente se comparado com as emitidas pelo Tribunal de Justiça da União Europeia (TJUE) -, o TPR acaba se debruçando sobre construções jurisdicionais que atuam de forma maciça na solução de conflitos e que possuem uma gama de elementos jurisprudenciais necessários ao tratamento do caso de violação do Princípio do livre comércio aplicado aos pneus reconstituídos.

Destarte, o TPR diante do vazio normativo do Mercosul, utiliza-se de outras experiências integracionistas que detalharam a questão em suas jurisprudências. ${ }^{81}$ Ao estabelecer que o objeto da controvérsia inclui a Lei e seu conteúdo incompatível, o Tribunal inspira-se de forma visceral na tese vigorante do Tribunal de Justiça

\footnotetext{
${ }^{80}$ Laudo n. 1/2005, considerando 10.

${ }^{81}$ O TPR aponta algumas linhas de conduta adotadas pelo Tribunal de Justiça andino e pelo TJUE que servem de apoio a situação fática. O acórdão "modelo" para a fixação de critérios de omissão à exceção ao Livre comércio é Comissão/Áustria-assunto C-320/03, cuja sentença foi prolatada em 15 de novembro de 2005 .
} 
andino que se utiliza do descumprimento continuado no qual a conduta infratora se perfaz, independentemente do texto normativo que a regulamenta.

Sobre os critérios interpretativos da exceção alegada pelas partes na controvérsia, o Tribunal Permanente de Revisão não se satisfaz com as alegações feitas pelas partes no laudo em revisão. Logo, utiliza-se do acórdão do TJUE, fixando quatro critérios de análise das exceções ao livre comércio. ${ }^{82}$ Sob esse critério, o TPR considera que o dano não é grave nem irreversível, e tampouco merece uma medida tão gravosa quanto à proibição imposta pela Argentina à importação dos pneus reconstituídos. ${ }^{83}$

Sobre a questão probatória, o Tribunal analisa as provas que foram apresentadas ao Tribunal arbitral. E como no procedimento revisional, o Tribunal Permanente de Revisão não receberá novas provas, atem-se àquelas constantes no laudo em revisão. ${ }^{84}$ Resolve, portanto, em discordância com entendimento do Tribunal $a d$ hoc que considerou a inversão do ônus da prova no procedimen-

82 Argentina e Uruguai no laudo arbitral emitido em 25 de outubro de 2005 indicam os critérios que atentem sobre a exceção ao Princípio do Livre Comércio, entretanto o TPR se utiliza da jurisprudência comunitária para análise das exceções cabíveis ao caso concreto, de modo que em primeiro lugar vem analisar se a medida adotada pela Argentina corresponde a uma restrição ao livre comércio; em segundo lugar vem analisar se houve caráter discriminatório na medida adotada e para isso se utiliza do critério de discriminação direta e indireta. Em terceiro lugar o TPR vem analisar se há justificativa ou não para a medida proibitiva a importação em prejuízo do Uruguai, de modo a analisar se a medida atendeu aos elementos de adequação, necessidade e proporcionalidade. O Tribunal diante disso precisa avaliar se a aplicação do artigo 50 do Tratado de Montevidéu, incorporado ao TA em seu artigo 2, b foi interpretado de forma correta no caso concreto, uma vez que a recorrida veio alegar que a Lei proibitiva foi adotada visando proteger o meio-ambiente, elemento que se enquadra como exceção ao Princípio do livre Comércio. Em quarto lugar vem avaliar a questão da proporcionalidade, que deverá estar atrelada à necessidade e aos meios que sejam menos restritivos do comércio. Ref. Laudo n. 1/2005, considerando 14 e ss.

${ }^{83}$ Laudo n. 1/2005, considerando 15.

${ }^{84}$ A atuação do TPR no tocante às questões probatórias do procedimento de revisão é diferente da sua atuação em única instância. Nesta às partes anexarão em seus textos as provas documentais de que disponham e proporão outras não disponíveis naquele momento. O TPR decidirá sobre a admissibilidade e a pertinência das provas apresentadas e propostas e decidirá o prazo razoável para seu diligenciamento no prazo máximo de 30 (trinta) dias. Além disso, o TPR poderá requerer que as partes apresentem dentro de um prazo determinado documentos adicionais ou que completem outras provas já apresentadas e determinar que apresentem toda e qualquer prova que considerar necessárias. to, por caber ao demandante provar que a produção de pneus reconstituídos é segura e não constitui perigo ecológico. O TPR, no entanto, esclarece que a inversão do ônus da prova em matéria de livre comércio não existe, e ainda que existisse recairia sobre a Argentina, já que é ela quem oferece a exceção àquele princípio, cabendo-lhe assim fazer prova que a sustente.

Outro ponto que o Tribunal não prescinde em destacar é a aplicabilidade dos Princípios de Direito Internacional Público invocados pelo Uruguai, ressaltando que sua atuação tem como ponto principal a interpretação dos instrumentos normativos do Mercosul em detrimento de outras regras de Direito Internacional que só serão aplicadas subsidiariamente, em função do Princípio da autonomia do Direito da Integração. ${ }^{85}$ Dessa forma, o Tribunal Permanente de Revisão, ainda que se valha por analogia da utilização da Jurisprudência Comunitária, resolve apresentar em seu primeiro laudo a generalidade com que o laudo arbitral pelo Tribunal ad hoc foi emitido e o desapontamento pela adoção de critérios rasteiros para decidir a controvérsia.

O Tribunal Permanente de Revisão reafirma a aplicabilidade das normas mercosulinas em relação às controvérsias que se apresentam. Assim, ainda que as partes tentem se valer da normativa internacional geral, confirma que a evolução das normas e a disposição dos órgãos condutores de aperfeiçoarem cada vez mais o Sistema contribuem para uma maior segurança jurídica aos Estados. Conclui, portanto que o laudo emitido pelo Tribunal ad hoc deve ser revogado pelos seguintes fundamentos. São eles: (i) que o laudo possui graves erros jurídicos; e (ii) que a Lei argentina é incompatível com a normativa do Mercosul, devendo, portanto, ser revogada ou modificada dentro do prazo de cento e vinte dias. Além disso, determina a vedação da República Argentina de adotar ou empregar qualquer medida que seja contrária à decisão, ou que crie obstáculos à sua aplicação.

\subsubsection{Recurso de esclarecimento}

Considerando a decisão do Tribunal Permanente de Revisão em revogar a decisão do Tribunal ad hoc, a

\footnotetext{
${ }^{85}$ É o caso do Princípio do estoppel invocado pelo Uruguai na demanda em questão, de Direito Internacional que não pertence nem ao Direito Originário, nem ao Direito Derivado e não está integrado como Princípio específico que rege o Mercosul.
} 
Argentina solicita o Recurso de esclarecimento do laudo arbitral que deu por compatível sua Lei proibitiva.

No caso em análise, a solicitação argentina é baseada no esclarecimento de 31 (trinta e um) itens do Laudo n.1/2005. ${ }^{86}$ Logo, caberá ao TPR analisar o conteúdo de cada item apresentado pelo Estado solicitante.

Observa-se que a solicitação da Argentina tem a intenção de levar o Tribunal a realizar uma nova revisão. No entanto, uma segunda revisão não é possível, e nos parece que é esse o intuito da solicitante: uma nova revisão que venha favorecê-la e conduza a instância revisora a erro na análise de pelo menos um dos 31 (trinta e um itens) levados a esclarecimento, e que deverão ser refutados pelo Tribunal item por item. Além disso, o Recurso interposto pelo Estado argentino não conduzirá à suspensão do cumprimento do laudo, e ainda que solicite seu esclarecimento, a decisão é inapelável e obrigatória, devendo ser cumprida no prazo de 120 (cento e vinte) dias.

O Tribunal refuta cada um dos 31 (trinta e um) itens apresentados pela Argentina e sob o Laudo n. 1/2006, decide não acolher o recurso de esclarecimento, por considerá-lo utilizado de maneira inapropriada para pretender reabrir o debate manifestamente improcedente. ${ }^{87}$

\subsubsection{Questionamento das medidas compensatórias}

Revogado o laudo arbitral de 25 de outubro de 2005 pelo Laudo n.1/2005 e assumida a obrigação da Argentina em proceder na derrogação ou modificação da lei incompatível, esta deverá fazê-la no prazo de 120 (cento e vinte) dias. Passado o prazo fixado, e não sendo cumprido, o Uruguai terá a faculdade de aplicar, na forma do Protocolo de Olivos, as medidas compensatórias cabíveis. ${ }^{88}$

Dessa forma, o Uruguai adota algumas medidas consideradas excessivas pela República Argentina que invoca o

\footnotetext{
${ }^{86}$ O Recurso de esclarecimento solicitado pela Argentina foi interposto em 13 de janeiro de 2006. Como não foi possível o acesso ao documento por questões de confidencialidade, não foi possível presumir com base somente nos apontamentos do TPR quais são os 31 (trinta e um) pontos objetos desse esclarecimento.

${ }^{87}$ MERCOSUR. Laudo n. 1/2006 do Tribunal Permanente de Revisão constituído em 20 de dezembro de 2005. Disponível em: <http://www.mercosur.int/msweb/SM/es/Controversias/TPR/ TPR_Laudo001-2006_Recurso\%20de\%20Aclaratoria.pdf >. Acesso em: 07 Abr. 2012, considerando XXXIV, parágrafo $2^{\circ}$.

${ }^{88}$ As medidas compensatórias adotadas pelo Uruguai são materializadas no Decreto n. 142/2007, que fixa uma taxa global tarifária de 16\% à importação de pneus da Argentina.
}

Protocolo de Olivos para questioná-las. ${ }^{89}$ E por meio de uma petição apresentada em 03 de maio de 2007, solicita ao Tribunal Permanente de Revisão que se pronuncie pela primeira vez sobre o excesso de medidas compensatórias aplicadas pelo Uruguai em razão do descumprimento do Laudo $\mathrm{n}$. 1/2005 proferido pelo Tribunal Permanente de Revisão.

O Tribunal observa, primeiramente, a normativa mercosulina no tocante à ordem preferencial de adoção dessas medidas. E segundo ele, o Estado beneficiado pelo laudo deverá em primeiro lugar suspender as concessões ou obrigações equivalentes no mesmo setor afetado. ${ }^{90}$ Igualmente, esclarece a finalidade das medidas que visam "[...] solucionar uma situação de descumprimento jurisdicionalmente declarado do direito regional, as quais implicam em não só equilibrar as correntes comerciais afetadas pela violação, mas também defender outros fatores de índole não comercial."91

O Tribunal Permanente de Revisão precisará reunir elementos que lhe possibilitem adotar uma decisão firme sobre a proporcionalidade das medidas compensatórias adotadas pelo Uruguai. Não bastasse a ausência de precedentes jurisprudenciais sobre o elemento "proporcionalidade", o Tribunal envolve-se em uma confusão funcional acerca da competência da Secretaria do Mercosul para a elaboração de um relatório de colaboração referente às medidas adotadas pelo Uruguai. ${ }^{92}$

Um desafio enfrentado pelo Tribunal também é apreciar a analogia feita pela República Argentina ao utilizar a jurisprudência da OMC para basear suas alegações. ${ }^{93}$ No

${ }^{89}$ Artigo 32, n. 2 do PO.

${ }^{90}$ Artigo 31, n. 2 do PO.

${ }^{91}$ Laudo n. 1/2007, considerando 9.2.

92 O TPR solicita o apoio da Secretaria Administrativa do Mercosul para que possa reunir uma gama considerável de elementos que fortaleçam a convicção da instância. Através da solicitação de um relatório jurídico e econômico sobre os fluxos comerciais vem fundamentar sua decisão sobre a questão da proporcionalidade das medidas adotadas pelo Uruguai. No entanto, a Secretaria se nega a viabilizar o documento por carência de uma base de dados própria de comércio exterior e por considerar que a emissão de um relatório jurídico está fora de suas atribuições.

${ }^{93}$ A Argentina alega que os efeitos das medidas aplicadas pelo Uruguai provocam desvio de comércio, em particular em benefício ao Brasil e à China. Além disso, alega que há excesso nas referidas medidas que vem sendo aplicadas. Quanto ao não cumprimento do laudo, a Argentina assume que a demora no acatamento é decorrente dos procedimentos internos e prazos necessários para a aprovação de uma lei que modifique a de $n^{\circ} .25 .626$, alegação que, igualmente, não a exime de cumprir a decisão constante do laudo. 
entanto, o TPR em defesa do foro escolhido para dirimir a controvérsia e em prejuízo de outros foros, e.g. OMC sustenta que o Sistema de Solução de Controvérsias do Mercosul não possui caráter meramente comercial abarcando outras matérias igualmente importantes que perfilam o caminho de uma integração ampla. E conclui que “[...] o Mercosul não pode ser avaliado nem conceituado como um processo de mero equilíbrio entre as concessões comerciais e econômicas dos Estados Partes (...)." ${ }^{\text {94 }}$ Diante desta diferenciação, o Tribunal adota o critério de dano globalmente considerado, deixando de lado a tese de mero equilíbrio recíproco entre os fluxos comerciais dos Estados-Partes envolvidos.

Com referência à função dos árbitros no processo de controvérsia, requer-se extrema habilidade e se exige uma capacidade interpretativa muito grande, especialmente em face do próprio caráter de transitoriedade e evolução do Sistema e pela necessidade de busca do direito aplicável caso a caso. Destarte, o Tribunal define na jurisprudência comunitária o que a normativa mercosulina silencia, além de avaliar os critérios de proporcionalidade das medidas adotadas pelo Uruguai. ${ }^{95}$

O Tribunal Permanente de Revisão estabelece que a proporcionalidade está relacionada com o dano causado em termos econômicos ou comerciais e o dano institucional que envolve, no caso em análise, a perda de empregos. Destaque-se que a responsabilidade do Tribunal em observar o dano causado é grande, já que ele agrega uma série de considerações que vão além das afetações econômicas dos Estados-Partes.

A evolução do Sistema acompanhou o crescimento do bloco, tomando em conta sua experimentação mais humana, voltada para as questões sociais. A relação de trabalho, que muitas vezes se rompe pelos prejuízos advindos de certas controvérsias, é um aspecto importante a ser ponderado pelo Tribunal. Logo, segundo o Tribunal, uma decisão não cumprida no contexto presente de uma construção integracionista ampla com o Mercosul gera

${ }_{94}$ Laudo n. 1/2007, considerando 7.5.

${ }^{95}$ O TPR se baseia no Comunicado da Comissão da CE n. 96/C 242/7 que adota o critério da gravidade da infração, da sua duração e da necessidade de garantir o efeito coercitivo da sanção para evitar a reincidência. danos que extrapolam a relação puramente comercial. ${ }^{96}$ Decide, portanto, admitir as medidas compensatórias adotadas pelo Uruguai, considerando-as proporcionais e não excessivas.

\subsubsection{Pronunciamento sobre o descumprimento do laudo}

A República do Uruguai - diante do não acatamento do laudo que segundo ela perdura - decide levar a consideração do Tribunal Permanente de Revisão para seu pronunciamento. O reclamante alega que a Argentina insiste no descumprimento do Laudo n. 1/2005 ao sancionar uma Lei que apenas ameniza a proibição de importação dos pneus contida na Lei 25.656/02, mas não a elimina.

Para se pronunciar, o Tribunal será composto, via de regra, pelo mesmo corpo arbitral que proferiu a decisão objeto do descumprimento. No entanto, precisa primeiramente enfrentar um incidente processual apresentado pela Argentina, que considerou necessária a realização de novo sorteio para substituir árbitro titular demitido. Sobre esse imbróglio, o Tribunal decide nomear o árbitro suplente para exercer a função desempenhada pelo titular, como estabelece o Protocolo de Olivos. ${ }^{97}$

Sob o Laudo n. 1/2008, ${ }^{98}$ o Tribunal terá competência para analisar a nova Lei promulgada pela Argentina em face das normas impostas pelo Laudo n.1/2005. Destaque-se que a insistência do Estado demandado em ressaltar o vazio normativo do Mercosul põe o Tribunal

\footnotetext{
${ }^{96}$ A proporcionalidade deve ter em conta a dimensão territorial e a potência econômica dos Estados envolvidos. Como o processo envolve o descumprimento do Laudo n. 1/2005 pela Argentina e a adoção de medidas compensatórias pelo Uruguai em represália ao não cumprimento da decisão, o Tribunal precisa verificar qual das ações é mais nociva. E conclui que, levando-se em conta as assimetrias em termos de tamanho e economia das medidas impostas pelo Uruguai, estas afetam a economia argentina de forma simbólica, enquanto que o mesmo não se pode afirmar da afetação pelo descumprimento do laudo em relação à economia do Uruguai. Ref. ao Laudo n. $1 / 2007$, p.13, item IV. O laudo aponta que as exportações do Uruguai para a Argentina correspondem no ano de 2000 a $43,4 \%$ das exportações que o país realiza, enquanto que as da Argentina para o Uruguai correspondem a $2 \%$.

${ }^{97}$ A resolução plenária realizada em 18 de março de 2008 é formada para resolver o recurso interposto pela República Argentina requerendo novo sorteio de árbitros em virtude da demissão do Dr. Fernández de Brix.

${ }^{98}$ Laudo n. 1/2008 constituído para dirimir a divergência sobre o cumprimento do Laudo n. 1/05 iniciada pela República Oriental do Uruguai.
} 
à prova e o instiga a fixar critérios variados de interpretação, além de refutar as alegações da Argentina quanto ao direito a ser aplicado no caso concreto.

A República Argentina promulga uma lei que ameniza o caráter discriminatório vigente na lei anterior, no entanto a discriminação persiste. Além disso, fundamenta-a em argumentos já indeferidos pelo Tribunal no Laudo n. 1/2005, laudo que tem força de coisa julgada e não prevê meios de escusa de caráter suspensivo ou interruptivo do prazo fixado, que desobrigue o Estado argentino de cumprir a decisão.

Ademais, o Tribunal fixou os critérios de averiguação das exceções permitidas ao livre comércio no Laudo n. 1/2005. Logo, uma vez não atendidos, o laudo será considerado descumprido. E assim observa o Tribunal, que decide descumprido o Laudo $1 / 2005$, já que a Lei $n$. 26.329 promulgada não supõe seu acatamento, devendo ser modificada ou revogada. Além disso, decorrido o prazo de (120) dias para cumprimento, o Tribunal considera que as medidas compensatórias adotadas pelo Uruguai podem ser mantidas.

Note-se que o modelo intergovernamental adotado pelo Mercosul não possibilita - no caso de descumprimento do laudo - a adoção de medidas de caráter pecuniário que forcem o Estado não cumpridor a implementar o conteúdo da decisão. Assim, a manutenção das medidas compensatórias acaba sendo considerada o meio mais próximo de cumprir esse papel, ainda que fique a cargo da parte beneficiada pela decisão.

Salienta-se que, após a publicação do Laudo n.1/2008, o Grupo Mercado Comum adotou a Resolução n. 25/08 para criação de um grupo ad hoc para a adoção de uma política comum em matéria de produção de pneus reconstituídos que atente para as questões ambientais, desde sua produção até sua destinação final.

\section{Conclusão}

O Mercosul foi constituído por meio do Tratado de Assunção em 26 de março de 1991, no momento de um imperativo no que toca ás relações econômicas vivenciadas entre seus Estados-Membros, nomeadamente entre Brasil e Argentina. Seu propósito inicial era a conquista de um mercado comum, uma união aduaneira sem fronteiras alfandegárias. No entanto, o bloco experimenta caminhos em outras direções, tais como: meio ambiente, educação, saúde e redução de assimetrias.

O Mercosul mostra-se mutável e adaptável a um processo evolutivo cujos patamares vêm sendo erguidos de acordo com as necessidades que emanam do bloco, e daquelas que estejam de acordo com seus objetivos de desenvolvimento. Assumida sua natureza transitória nos próprios instrumentos em seu seio criados, o Mercosul evoluiu rumo à criação de um Sistema de Solução de Controvérsias, e na atualidade vem aprofundá-lo. Esse Sistema nasceu em razão da necessidade da criação de uma estrutura capaz de atender às questões de dissenso e conflitos que surgissem entre os Estados e de alcançar os objetivos estabelecidos no Tratado de Assunção.

O Tratado de Assunção veio estabelecer no seu Anexo III um Sistema transitório referente às controvérsias que surgissem no processo de transição para o almejado mecanismo que nasceria no âmbito do Mercosul. No entanto, limitou-se a assegurar as instâncias cabíveis à solução do litígio. Quanto ao Sistema Permanente para Solução de Controvérsias, ele deveria estar funcionando até 31 de dezembro de 1994. No entanto, os Estados-Membros resolveram pela adoção de um Protocolo anexo ao Tratado de Assunção, que veio dispor de um sistema suscetível à reforma e às alteraç̃es sensíveis até que viesse a ser verdadeiramente conformado.

Assim, o Protocolo de Brasília foi criado, definindo as três fases possíveis para por termo à questão litigiosa. Além disso, instituiu a Secretaria Administrativa do Mercosul como quarto órgão encarregado das tarefas burocráticas. Mas, nada estabeleceu sobre a criação de um órgão de caráter jurisdicional instituído dentro do bloco.

Somente a partir da entrada em vigor do Protocolo de Olivos, pode-se afirmar que o Sistema de Solução de Controvérsias foi aperfeiçoado, trazendo algumas inovações e resolvendo algumas lacunas existentes no Protocolo de Brasília. Aperfeiçoamento que, como observamos, favoreceu o amadurecimento do sistema no tocante à eficiência da resolução de litígios.

As inovações advindas do Protocolo de Olivos são relativas à possibilidade de escolha do foro para a solução de controvérsias; a possibilidade de criação de mecanismos relativos a aspectos técnicos; a ampliação do número de árbitros que compõe o Tribunal Arbitral ad hoc; e a definição do objeto da controvérsia. Mas, sua maior inovação é a criação do Tribunal Permanente de Revisão como órgão multifun- 
cional que agrega funções não antes desempenhadas por outro órgão do Mercosul.

O Tribunal Permanente de Revisão supre diversas lacunas do Sistema de Solução de Controvérsias, exercendo importantes funções tanto no âmbito contencioso como consultivo. E a possibilidade das partes acessarem diretamente ao TPR e em única instância congratula-o com as mesmas competências de um Tribunal ad hoc, somado ao diferencial de ser um tribunal permanente que nasceu dentro do Mercosul, sem o aspecto temporário.

No caso ilustrado, que envolve a República Oriental do Uruguai e a República Argentina - primeiro desafio do TPR como órgão revisor -, o TPR vem atuar de forma firme esclarecendo que o Mercosul não é um mecanismo de mero equilíbrio econômico, que possui regras próprias e, ainda que seja possível aplicar as normas de Direito Internacional Público, só serão utilizadas numa solução de controvérsias subsidiariamente e nos casos de vazio normativo.

O Sistema ainda enfrenta desafios quando a normativa silencia. No entanto, não prescinde em utilizar as jurisprudências daquelas construções integracionistas mais experientes e atuantes em analogia ao caso concreto. Conduta que demonstra amadurecimento no tocante às relações estremecidas entre as partes que extrapolam a solução estritamente econômica.

O Tribunal Permanente de Revisão foca-se em adotar critérios que tenham como pano de fundo sua experimentação mais humana, não restrita às perdas ou prejuízos advindos da proibição de importação de um determinado bem. Dessa forma, apesar dos procedimentos cabíveis para solução de controvérsias mostrarem-se céleres, na atualidade como mecanismo em processo de maturidade vislumbra-se um compromisso muito grande com o objeto da controvérsia e com as questões que o envolvem. Além disso, o atual Sistema de Solução de Controvérsias rege as relações entre as partes sob o compromisso de consolidar as bases que sustentam o Mercosul e, estima-se, trilha um caminho interessante rumo à consolidação de um tribunal regional que favorecerá todos os Estados sul-americanos.

\section{Referências}

ACCIOLY, Elizabeth. O Atual mecanismo de solução de controvérsias do Mercosul: o Protocolo de Olivos. Revista da Faculdade de Direito, Lisboa, v. 45, n. 13, p. 204-226, Jan. 2004. v. 45, n. 13, p. 206, Jan 2004.

BAPTISTA, Luis Olavo. Solução de divergências no Mercosul. In: Mercosul: seus efeitos jurídicos, econômicos e políticos nos Estados-Membros. Porto Alegre: Apiliada, 1997. p. 157-186.

BASSO, Maristela. A consolidação da integração no Cone Sul: reflexões. Revista de Estudos Europeus, Coimbra, v. 1, n. 1, p. 151-156, jan./jun. 2007.

CAMINHA, Maria do Carmo Puccini. O acesso à jurisdição no espaço integrado do Mercosul. Revista da Faculdade de Direito, Coimbra, v. 43, n. 1, p. 555-576, Jan. 2002.

EKMEKDJIAN, Miguel Angel. Introducción al derecho comunitario latinoamericano: con especial referencia al Mercosur. Buenos Aires: Depalma, 1996.

FONTOURA, Jorge. A revisão institucional do Mercosul: Ouro Preto II. Revista de Estudos Europeus, Coimbra, v. 1, n. 1, p. 291-297, jan./jun. 2007.

GOMES, Eduardo Biacchi. O Protocolo de Olivos: alterações no Sistema de Solução de Controvérsias do Mercosul e perspectivas. Revista da Faculdade de Direito, Curitiba, v. 37, p. 157-167, Jan. 2002.

GRECO, Leonardo. Solução de controvérsias e protocolos do Mercosul. Revista Brasileira De Direito Comparado, Rio de Janeiro, n. 16, p. 110-124, Jan./Jun. 1999.

MARQUES, Claudia Lima. O "Direito do Mercosul": direito oriundo do Mercosul, entre Direito Internacional clássico e novos caminhos de integração. Revista da Universidade Federal do Paraná, Curitiba, v. 35, n.1, p. 73-100, Jan. 2001. v. 35, n. 1, p. 74, Jan 2001

MERCOSUR. Dec. CMC n. 02/07. Regulamenta o procedimento de solicitação de Opiniões Consultivas ao Tribunal Permanente de Revisão. Disponível em: <http:// www.mercosur.int/innovaportal/v /634/1/secretaria/ decisiones_2007>. Acesso em: 07 Abr. 2012.

MERCOSUR. Dec. CMC n. 03/08. Estabelece o programa marco de ciência, tecnologia e inovação do Mercosul. Disponível em: < http://www.mercosur.int/ innovaportal/v/584/1/secretaria/decisiones_2008>. Acesso em: 07 Abr. 2012.

MERCOSUR. Dec. CMC n. 07/06. Sobre liberalização do comércio. Disponível em: < http://www.mercosur. int/innovaportal/v/1038/1/secretaria/decisiones_2006 >. Acesso em: 09 Abr. 2012. 
MERCOSUR. Dec. CMC n. 23/04. Estabelece o procedimento para atender casos excepcionais e de urgência. Disponível em:< http://www.mercosur.int/ innovaportal/v/580/1/secretaria/decisiones_2004>. Acesso em: 10 Abr. 2012.

MERCOSUR. Dec. CMC n. 30/04. Estabelece as regras modelo de procedimento para os Tribunais arbitrais ad hoc do Mercosul. Disponível em: < http://www.mercosur. int/innovaportal/v/580/1/secretaria/decisiones_2004 >. Acesso em: 10 Abr. 2012.

MERCOSUR. Dec. CMC n. 30/05. Aprova as regras de procedimento do Tribunal Permanente de Revisão. Disponível em: < http://www.mercosur.int/ innovaportal/v/1066/1/secretaria/decisiones_2005 >. Acesso em: 07 Abr. 2012.

MERCOSUR. Dec. CMC n. 36/08. Designa os árbitros do Tribunal Permanente de Revisão. Disponível em: <http:// www.mercosur.int/innovaportal/v/584/1/secretaria/ decisiones_2008 >. Acesso em: 08 Abr. 2012.

MERCOSUR. Dec. CMC n. 37/03. Estabelece o regulamento do Protocolo de Olivos para solução de controvérsias. Disponível em: <http://www.mercosur. int/innovaportal/v/579/1/secretaria/decisiones_2003>. Acesso em: 09 Abr. 2012.

MERCOSUR. Laudo n. 1 do Tribunal Permanente de Revisão constituído em 25 de outubro de 2005. Disponível em: <http://www.mercosur.int/msweb/ SM/es/Controversias/TPR/TPR_Laudo001-2005_ Importacion $\% 20 \mathrm{de} \% 20 \mathrm{Neumaticos} \% 20$ Remoldeados. pdf>. Acesso em: 03 Jan. 2012.

MERCOSUR. Laudo n. 1 do Tribunal Permanente de Revisão constituído em 8 de julho de 2007. Disponível em: <http://www.mercosur.int/msweb/portal\%20 intermediario/ES/documentos/Laudo_01_07_pt.pdf $>$. Acesso em: 03 Jan. 2012.

MERCOSUR. Laudo n. 1/2006 do Tribunal Permanente de Revisão constituído em 20 de dezembro de 2005. Disponível em: <http://www.mercosur.int/msweb/SM/es/ Controversias/TPR/TPR_Laudo001-2006_Recurso\%20 de\%20Aclaratoria.pdf>. Acesso em: 07 Abr. 2012.

MERCOSUR. Laudo n. 2 do Tribunal Arbitral constituído em 27 de setembro de 1999. Disponível em: <http:// www.mercosur.int/msweb/portal\%20intermediario/pt/ controversias/II\%20LAUDO.pdf>. Acesso em: 28 Nov. 2011.

MERCOSUR. Laudo n. 1 do Tribunal Arbitral constituído em 28 de abril de 1999. Disponível em: <http://www.mercosur. int/msweb/portal\%20intermediario/pt/controversias/I\%20 LAUDO.pdf>. Acesso em: 23 Nov. 2011.
MERCOSUR. Opinião Consultiva n. 1/2007 recebida pelo Tribunal Permanente de Revisão em 21 de dezembro de 2006. Disponível em: <http://www.mercosur. int/innovaportal/file/PrimeraOpinionConsultivaVersionfinal.pdf? contentid=377\&version $=1$ \&filename $=$ PrimeraOpinionConsultiva-Versionfinal.pdf $>$. Acesso em: 13 Nov. 2011.

MERCOSUR. Protocolo de Ouro Preto firmado em 17 de dezembro de 2004. Disponível em: <http://www.mercosur. int/innovaportal/file/724/1/cmc_1994_protocolo_ouro_ preto_pt.pdf>. Acesso em: 07 Abr. 2012.

PARAGUAY. Ministerio de Relaciones Exteriores. Protocolo de Brasília firmado em 17 de dezembro de 1991. Disponível em: <http://www.mre.gov.py/ dependencias/tratados/mercosur/registro\%20mercosur/ Acuerdos/1991/portugués/2.Protocolo\%20de\%20 Brasilia.pdf>. Acesso em: 28 Nov. 2011.

PARAGUAY. Ministerio de Relaciones Exteriores. Protocolo de Olivos firmado em 18 de fevereiro de 2002. Disponível em: <http://www.mre.gov.py/ dependencias/tratados/mercosur/registro\%20mercosur/ Acuerdos/2002/portugués/51.\%20Protocolo\%20de $\% 20$ Olivos.pdf>. Acesso em: 08 Abr. 2012.

PARAGUAY. Ministerio de Relaciones Exteriores. Tratado de Assunção e seus anexos firmado em 26 de março de 1991. Disponível em: <http://www.mre.gov.py/ dependencias/tratados/mercosur/registro\%20mercosur/ Acuerdos/1991/portugués/ 1 . Tratado\%20do\%20 Assunção.pdf>. Acesso em: 10 Abr. 2012.

PUÑAL, Antonio Martinez. O sistema de fontes do Mercosul: problemas normativos e bases para a resolução. Scientia Ivridica, Braga, Tomo LVI, n. 312, p. 669-687, out./nov. 2007.

RIDRUEJO, José A. Pastor. Curso de derecho internacional publico y organizaciones internacionales. Madrid: Tecnos, 2008.

VELLASCO, Manuel Diez de. Instituciones de derecho international público. Madrid: Tecnos, 2006.

VELLASCO, Manuel Diez de. Las organizaciones internacionales. Madrid: Tecnos, 1999. 
Para publicar na Revista de Direito Internacional, acesse 0 endereço eletrônico www.publicacoesacademicas.uniceub.br. Observe as normas de publicação, para facilitar e agilizar o trabalho de edição. 